\title{
GYF-21, an Epoxide 2-(2-Phenethyl)-Chromone Derivative, Suppresses Innate and Adaptive Immunity via Inhibiting STAT1/3 and NF-KB Signaling Pathways
}

\author{
Ran Guot, Yun-Fang Zhao+, Jun Li, Yu-Fan Gu, Hui-Xia Huo, Shan-Shan Li, \\ Yue-Lin Song, Zhi-Xiang Zhu* and Peng-Fei Tu*
}

Modern Research Center for Traditional Chinese Medicine, School of Chinese Materia Medica, Beijing University of Chinese Medicine, Beijing, China

\section{OPEN ACCESS}

Edited by:

Chiranjib Chakraborty,

Galgotias University, India

Reviewed by:

Martina Schmidt,

University of Groningen, Netherlands

Michael Hickey,

Monash University, Australia

*Correspondence:

Zhi-Xiang Zhu

ahssfxgt@163.com

Peng-Fei Tu

pengfeitu@163.com

tThese authors have contributed equally to this work.

Specialty section:

This article was submitted to Experimental Pharmacology and Drug

Discovery,

a section of the journal

Frontiers in Pharmacology

Received: 20 February 2017

Accepted: 03 May 2017

Published: 22 May 2017

Citation:

Guo R, Zhao Y-F, Li J, Gu Y-F, Huo H-X, Li S-S, Song Y-L, Zhu Z-X and Tu P-F (2017) GYF-21,

an Epoxide 2-(2-Phenethyl)-

Chromone Derivative, Suppresses

Innate and Adaptive Immunity via Inhibiting STAT1/3 and NF- $\kappa B$

Signaling Pathways.

Front. Pharmacol. 8:281.

doi: 10.3389/fphar.2017.00281
Multiple sclerosis is a chronic inflammatory autoimmune disease of the central nervous system characterized by demyelinating plaques and axonal loss. Inhibition on over activation of innate and adaptive immunity provides a rationale strategy for treatment of multiple sclerosis. In the present study, we investigated the inhibitory effects of GYF21, an epoxide 2-(2-phenethyl)-chromone derivative isolated from Chinese agarwood, on innate and adaptive immunity for revealing its potential to treat multiple sclerosis. The results showed that GYF-21 markedly inhibited the activation of microglia, and dendritic cells as well as neutrophils, all of which play important roles in innate immunity. Furthermore, GYF-21 significantly suppressed adaptive immunity via inhibiting the differentiation of naive CD4 ${ }^{+} \mathrm{T}$ cells into T helper 1 (Th1) and T helper 17 (Th17) cells, and suppressing the activation, proliferation, and IFN- $\gamma$ secretion of $\mathrm{CD} 8^{+} \mathrm{T}$ cells. The mechanism study showed that GYF-21 evidently inhibited the activation of STAT1/3 and NF-kB signaling pathways in microglia. In conclusion, we demonstrated that GYF21 can significantly inhibit innate and adaptive immunity via suppressing STAT1/3 and NF-kB signaling pathways, and has potential to be developed into therapeutic drug for multiple sclerosis.

Keywords: multiple sclerosis, epoxide 2-(2-phenethyl)-chromone, innate immunity, adaptive immunity, STAT1/3 signaling pathway

\section{INTRODUCTION}

As an organ-specific autoimmune disease, multiple sclerosis (MS) is manifested by chronic inflammatory demyelination of the central nervous system (CNS) and is one of the foremost causes of non-traumatic neurological disability in young adults (Goverman, 2009; Dendrou et al., 2015). $\mathrm{CD}^{+} \mathrm{T}$ cell-mediated autoimmunity has long been accepted as one of the most important aspects of MS pathogenesis, especially for the early initiation of diseases. T helper 1 (Th1) cells, characterized by the production of interferon- $\gamma$ (IFN- $\gamma$ ), have been considered as the type of effector helper $\mathrm{T}$ cells that mediate the pathogenesis of MS; subsequently studies have indicated that interleukin 17 (IL-17)-producing $\mathrm{T}$ helper (Th17) cells are involved and play more important role in this pathogenesis than Th1 cells (Ogura et al., 2008; McGeachy et al., 2009; El-Behi et al., 2011; Lazarevic et al., 2011; 
Goldmann and Prinz, 2013; Martin et al., 2016). Myeloid innate immune cells, such as microglia, dendritic cells, and neutrophils, are prominent constituents of inflammatory infiltrates in the CNS during MS. These cells not only serve as antigen presenting cells for the reactivation of infiltrating myelin-reactive $\mathrm{CD} 4^{+} \mathrm{T}$ cells but also are thought to directly result in tissue damage through secretion of toxic factors (Wu and Laufer, 2007; Comabella et al., 2010; Starossom et al., 2012; Goldmann and Prinz, 2013; Jaillon et al., 2013; Nuyts et al., 2013; Steinbach et al., 2013; StrachanWhaley et al., 2014).

However, only a few drugs, including interferon $\beta$, fingolimod, teriflunomide, dimethyl fumarate, glatiramer acetate, natalizumab, daclizumab, and mitoxantrone, are currently available for MS patients, and their clinical application is limited by poor curative effects and deleterious adverse effects (Hydleburg and D’Aversa, 2014; Rush et al., 2015; Torkildsen et al., 2016). Therefore, the identification of immunosuppressive drugs with new mechanism and lesser adverse effects to treat MS is very urgently needed.

Chinese agarwood, a famous traditional Chinese medicine, has been used as a sedative, analgesic and digestive agent ( $\mathrm{Wu}$ et al., 2012; Huo et al., 2015; Li et al., 2015; Zhu et al., 2016). Previously, we isolated dozens of 2-(phenethyl)-chromone derivatives from ethyl acetate extract of Chinese agarwood. In the preliminary bioactivity screening assays, we found that several 2-(phenethyl)-chromone derivatives significantly inhibited interleukin-6 (IL-6) production by LPS induced microglia, suggesting that these 2-(phenethyl)-chromone derivatives may have potential immunosuppressive activity (Huo et al., 2015; Zhu et al., 2016). Among these active 2-(phenethyl)-chromone derivatives, the compound ( $1 \mathrm{a} S, 2 S, 3 S, 7 \mathrm{~b} R)-2,3$-dihydroxy5-(4-methoxyphenethyl)-2, 3-dihydro-1aH-oxireno $\left[\begin{array}{ll}2, & 3-f]\end{array}\right.$ chromen-7 (7bH)-one (GYF-21, Figure 1A), which was firstly identified by $\mathrm{Wu}$ et al., showed strongest activity (Wu et al., 2012). In our previous study, we had demonstrated inhibitory effects of GYF-17, a 2-(phenethyl)-chromone derivative, on the activation of macrophages and microglia (data not shown) via mainly blocking STAT1/3 signaling pathways (Zhu et al., 2016). In view of the stronger inhibitory effects of GYF-21 on microglia and the important roles that STAT1/3 signaling pathways play in adaptive immune cells, we will investigate the inhibitory activity of GYF-21 on innate and adaptive immunity and underlying mechanisms, as well as reveal its potential to treat multiple sclerosis.

\section{MATERIALS AND METHODS}

\section{Reagents}

GYF-21 was isolated from Chinese agarwood and the isolation procedure was described primarily (Huo et al., 2015). GYF21 was dissolved at a concentration of $25 \mathrm{mM}$ in dimethyl sulfoxide (DMSO). Cell Counting Kit-8 (CCK-8) was purchased from Beyotime, Co. (Shanghai, China). Lipopolysaccharide (LPS) from Escherichia coli O55: B5 was purchased from Sigma Chemicals, Co. (St. Louis, MO, United States). ELISA kits for determining TNF- $\alpha$, IL-6, IL- $1 \beta$, MCP-1, MIP- $1 \alpha$, IFN- $\gamma$, and
IgG were purchased from R\&D Systems (Minneapolis, MN, United States). The antibodies to p65, I- $\kappa$ B, p38, ERK1/2, JNK, STAT1, STAT3, and their phosphorylated forms were purchased from Cell signaling Technology (Beverly, MA, United States). Monoclonal antibodies (mAbs) conjugated to APC, APC, PE, FITC, PE, FITC, FITC, PE, PE-Cy7, Alexa Fluor 647, FITC, and PE (specific for Ly-6G, CD11c, CD11b, CD62L, CD69, CD25, CD80, CD86, CD4, CD8, IFN- $\gamma$, and IL-17A), and purified monoclonal antibodies (specific for CD3e, CD28, IFN- $\gamma$, and IL4) were obtained from Becton Dickinson (San Diego, CA, United States). Magnetic bead isolation kit for mouse $\mathrm{CD} 4^{+} \mathrm{T}$ cells, naive $\mathrm{CD}^{+}{ }^{+} \mathrm{T}$ cells and $\mathrm{CD} 8^{+} \mathrm{T}$ cells were purchased from Miltenyl Biotec (Bergisch Gladbach, Germany). Recombinant mouse GMCSF, IL-4, IL-12, IFN- $\gamma$, IL-6, and TGF- $\beta$ were purchased from PeproTech (Rocky Hill, NJ, United States).

\section{Isolation and Structural Identification of GYF-21}

The air-dried agarwood powder $(6.9 \mathrm{~kg})$ was refluxed with 95\% EtOH $(3 \mathrm{~h} \times 2.5 \mathrm{~h})$. After removal of ethanol by evaporation, the residues $\left(3.4 \mathrm{~kg}\right.$ ) were suspended in $\mathrm{H}_{2} \mathrm{O}$ and extracted with petroleum ether and ethyl acetate (EtOAc). The EtOAc fraction (400 g) was subjected to silica gel column chromatography (CC) and eluted with Petroleum ether-EtOAc (from 8:1 to 1:1) and $\mathrm{CHCl}_{3}-\mathrm{CH}_{3} \mathrm{OH}$ (from 20:1 to $1: 3$ ) to afford seven fractions (by TLC). Fraction 5 (86 g) was subjected to silica gel CC and eluted with $\mathrm{CH}_{2} \mathrm{Cl}_{2}-\mathrm{CH}_{3} \mathrm{OH}$ (from 80:1 to $\mathrm{CH}_{3} \mathrm{OH}$ ) to give four fractions: 5a-5d. Fraction 5b (18 g) was subjected to $\mathrm{CC}$ and eluted with $\mathrm{CH}_{2} \mathrm{Cl}_{2}-\mathrm{CH}_{3} \mathrm{OH}$ (8:1), then introduced onto RPODS column and eluted with $\mathrm{CH}_{3} \mathrm{OH}-\mathrm{H}_{2} \mathrm{O}$ (40:60). The stream was subjected to $\mathrm{CC}$ again and eluted with $\mathrm{CH}_{2} \mathrm{Cl}_{2}-\mathrm{CH}_{3} \mathrm{O} \mathrm{CH}_{3}$ (10:1) to give GYF-21 (12 mg).

Spectroscopic and spectrometric analyses were employed for structural identification and purity analysis of GYF-21. ${ }^{1} \mathrm{H}$ NMR and ${ }^{13} \mathrm{C}$ NMR spectra were recorded on a Varian $500 \mathrm{MHz}$ spectrometer (CA, United States) and deuterated dimethyl sulfoxide (DMSO- $d_{6}$ ) was utilized as residual solvent. Chemical shifts were expressed in parts per million (ppm). Mass spectra were recorded on Shimadzu LCMS-IT-TOF platform (Tokyo, Japan).

\section{Animals}

Male BALB/c and C57BL/6 mice (6-8 weeks old) were obtained from Charles River Laboratory China (Beijing, China) and maintained under specific pathogen-free conditions at a room temperature of $22 \pm 2^{\circ} \mathrm{C}$ and air humidity of $55 \pm 10 \%$ on a $12 \mathrm{~h} / 12 \mathrm{~h}$ light/dark cycle. All protocols conformed to guidelines in Beijing University of Chinese Medicine (Beijing, China), and animal care was performed in compliance with the Principles of Laboratory Animal Care. The study was approved by the Ethical Committee on Animal Research in Beijing University of Chinese Medicine.

\section{Cell Isolation and Culture}

The murine microglia cell line, BV-2 cells, was obtained from Beijing Union Medical University (Beijing, China) and maintained in high glucose DMEM medium supplemented with 
A

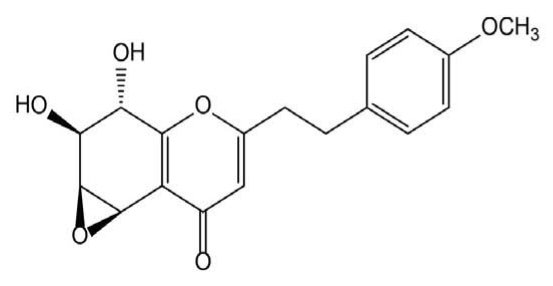

B

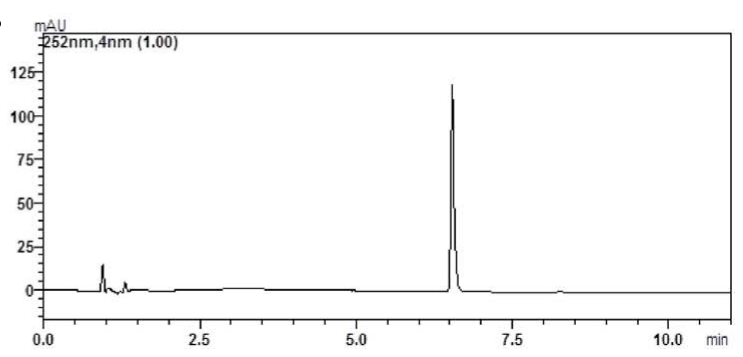

FIGURE 1 | Chemical structure (A) and chromatogram (B) of GYF-21.

$10 \%$ heat-inactivated $\mathrm{FBS}, 100 \mathrm{U} / \mathrm{ml}$ penicillin and $100 \mu \mathrm{g} / \mathrm{ml}$ streptomycin at $37^{\circ} \mathrm{C}$ under $5 \% \mathrm{CO}_{2}$.

Mouse marrow derived dendritic cells (BMDC) were generated as described (Varga et al., 2007). Briefly, single-cell suspensions from bone marrow of C57BL/6 mice were prepared and red blood cells were removed with lysis buffer $(10 \mathrm{mM}$ $\mathrm{NH}_{4} \mathrm{Cl}$ ). Then the bone marrow cells were seeded into 6-well tissue culture plate in complete medium (RPMI1640 medium containing $10 \%$ heat-inactivated FBS, $100 \mathrm{U} / \mathrm{ml}$ penicillin and $100 \mu \mathrm{g} / \mathrm{ml}$ streptomycin) for $2 \mathrm{~h}$ at $37^{\circ} \mathrm{C}$ under $5 \% \mathrm{CO}_{2}$. After the non-adherent cells were washed out, the adherent cells were cultured in the presence of $20 \mathrm{ng} / \mathrm{ml} \mathrm{GM-CSF}$ and $10 \mathrm{ng} / \mathrm{ml} \mathrm{IL-4}$ for 6 days, with a medium change every second day. The yield of $\mathrm{CD}_{11 \mathrm{c}^{+}}$cells was routinely greater than $50 \%$.

For the activation assay of neutrophils, bone marrow (BM) cells of $\mathrm{BALB} / \mathrm{c}$ mice were isolated by flushing the femur BM tissues with 1\% FBS-PBS, and single-cell suspension was obtained. Then the BM cells were maintained in IMDM medium supplemented with $2 \%$ heat-inactivated FBS, $100 \mathrm{U} / \mathrm{ml}$ penicillin and $100 \mu \mathrm{g} / \mathrm{ml}$ streptomycin at $37^{\circ} \mathrm{C}$ under $5 \% \mathrm{CO}_{2}$.

Mouse spleen of $\mathrm{BALB} / \mathrm{c}$ mouse was removed and singlecell suspension was generated by homogenization and passage through a $70 \mu \mathrm{m}$ cell strainer. Red blood cells were removed with lysis buffer. The remaining splenocytes were maintained in RPMI1640 medium supplemented with 10\% FBS, $100 \mathrm{U} / \mathrm{ml}$ penicillin and $100 \mu \mathrm{g} / \mathrm{ml}$ streptomycin at $37^{\circ} \mathrm{C}$ under $5 \% \mathrm{CO}_{2}$. To purify $\mathrm{CD}^{+}{ }^{+} \mathrm{T}$ cells, naive $\mathrm{CD} 4^{+} \mathrm{T}$ cells and $\mathrm{CD} 8^{+} \mathrm{T}$ cells, splenocytes were resuspended in $1 \mathrm{ml}$ FACS buffer (PBS, 0.5\% BSA, $2 \mathrm{mM}$ EDTA) and isolated with negative magnetic bead separation kits of $\mathrm{CD} 4^{+} \mathrm{T}$ cells, naive $\mathrm{CD} 4^{+} \mathrm{T}$ cells, and $\mathrm{CD} 8^{+}$ $\mathrm{T}$ cells according to the manufacturer's protocols. Cell purity was analyzed using flow cytometry (>90\%).

\section{Cytotoxicity Assay}

The BV-2 cells were inoculated into 96-well plates $\left(5 \times 10^{3}\right.$ cells/well). After incubated for $24 \mathrm{~h}$, the cells were treated with or without GYF-21 for $24 \mathrm{~h}$. Then $20 \mu \mathrm{l}$ of reagent in CCK8 was added into each well and incubated for $4 \mathrm{~h}$ according to the manufacture's protocols. The culture plate was detected at the wavelength of $450 \mathrm{~nm}$ on a microplate reader. The OD values indicated the levels of cell viability.

Splenocytes were seeded in 96-well plate $\left(1 \times 10^{6}\right.$ cells/well $)$ and were treated with or without GYF-21 for $24 \mathrm{~h}$. The levels of cell viability were detected as above.

\section{Analysis of mRNA Transcription and Secretion of Cytokines and Chemokines by Microglia}

For real-time fluorescence quantitative polymerase chain reaction (PCR) assay of $\mathrm{mRNA}$ transcription, $\mathrm{BV}-2$ cells were seeded in 6 -well plate $\left(2 \times 10^{5}\right.$ cells/well $)$. After incubated for $24 \mathrm{~h}$, the cells were treated with or without GYF-21 for $0.5 \mathrm{~h}$ and then stimulated with LPS. After stimulated $6 \mathrm{~h}$ by LPS, total RNA was extracted and reverse-transcribed into cDNA for $30 \mathrm{~min}$ at $42^{\circ} \mathrm{C}$ using $\mathrm{RT}$ kit. The cDNA was amplified by PCR Supermix kit. Sequences of the GAPDH, TNF- $\alpha$,IL-6, IL-1 $\beta$, MCP-1, and MIP- $1 \alpha$ primers are shown in Table 1. Amplification reactions were performed for 1 cycle at $95^{\circ} \mathrm{C}$ for $1 \mathrm{~min}, 40$ cycles at $95^{\circ} \mathrm{C}$ for $5 \mathrm{~s}, 60^{\circ} \mathrm{C}$ for $40 \mathrm{~s}$, followed by 1 cycle of melting curve determination on CFX96 Touch ${ }^{\text {TM }}$ PCR System (BioRad, Hercules, CA, United States). The amount of mRNA in each sample was calculated and normalized to the level of GAPDH mRNA.

For quantitative analysis of cytokine secretion, BV-2 cells were seeded in 96-well plate $\left(2 \times 10^{4}\right.$ cells/well). After incubated for $24 \mathrm{~h}$, the cells were treated with or without GYF-21 for $0.5 \mathrm{~h}$ and then stimulated with LPS. After stimulated $12 \mathrm{~h}$ by LPS, levels of TNF- $\alpha$, IL- 6 , IL- $1 \beta$, MCP-1, and MIP- $1 \alpha$ in the cell medium were measured by ELISA according to the manufacture's protocols.

TABLE 1 | Primer sequences used in RT-PCR.

\begin{tabular}{ll}
\hline Genes & Primer sequences \\
\hline TNF $\alpha$ & Forward 5'-CCCCTTATTGTCTACTCCT-3' \\
& Reverse 5'-AAAGCCCATTGAGTCCTTG-3' \\
IL-6 & Forward 5'-AAATAGTCCTCCTACCCCAA-3' \\
& Reverse 5'-CCGAGTAGATCTCAAAGTGAC-3' \\
IL-1 $\beta$ & Forward 5'-GAGCCCATCCTCTGTGACTC-3' \\
& Reverse 5'-TCAGCTCATATGGGTCCGACA-3' \\
MCP-1 & Forward 5'-ACCTGCTGCTACTCATCACC-3' \\
& Reverse 5'-CCATCCTTCTGGGGTCAG-3' \\
MIP-1 $\alpha$ & Forward 5'-ATTCCACGCCAATTCATCGTT-3' \\
& Reverse 5'-TCTGCCGGTTCTCTTAGTCA-3' \\
GAPDH & Forward 5'-GCGACTTCAACAGCAACTCC-3' \\
& Reverse 5'-CACCCTGTTGCTGTAGCCGT-3'
\end{tabular}




\section{A Cell viability of macrophages}

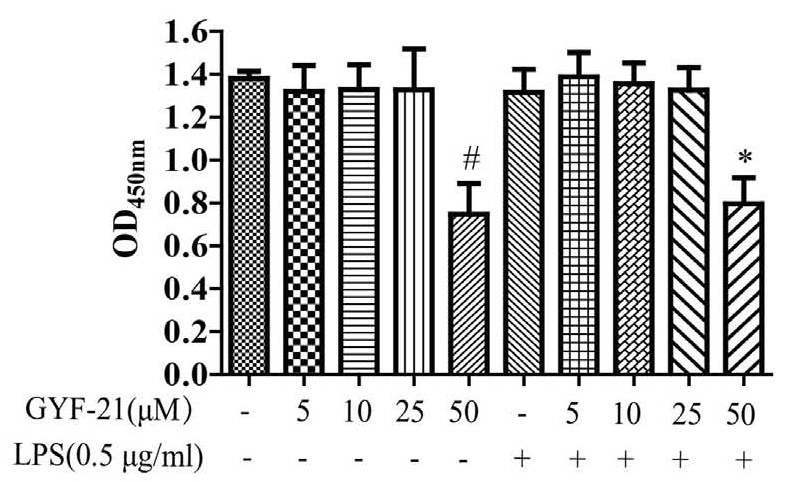

B Cell viability of Splenocytes

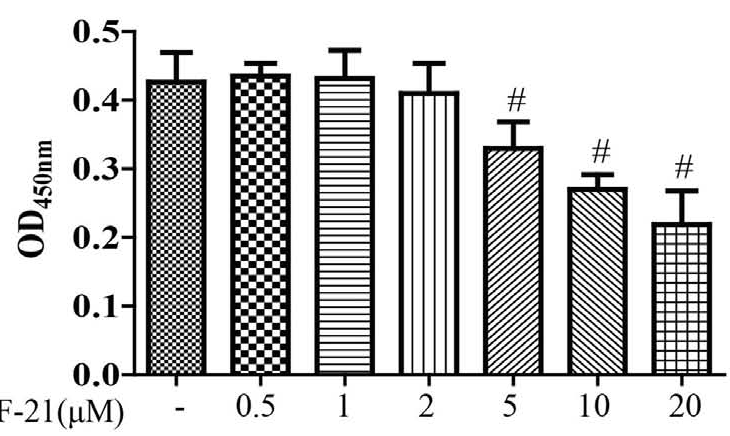

FIGURE 2 | Cytotoxicity of GYF-21 on microglia and splenocytes. BV-2 cells (A) and splenocytes (B) were treated with various concentrations of GYF-21 for $24 \mathrm{~h}$ and cell viability was determined with CCK-8. Data are representative of three independent experiments. ${ }^{\#} P<0.05$ vs. Vehicle; ${ }^{*} P<0.05$ vs. LPS.

\section{Activation Analysis of Dendritic cells}

BMDC were seeded in 48 -well plate $\left(1.5 \times 10^{5}\right.$ cells/well $)$. The cells were treated with or without GYF-21 for $0.5 \mathrm{~h}$ and then stimulated with $0.5 \mu \mathrm{g} / \mathrm{ml}$ LPS for $24 \mathrm{~h}$. The expressions of CD80 and CD86 on dendritic cells which were gated by CD11c were determined by flow cytometry on BD FACSCanto II (BD Biosciences, San Diego, CA, United States).

\section{Activation Analysis of Neutrophils}

Mouse BM cells were seeded in 24 -well plate $\left(1 \times 10^{6}\right.$ cells/well $)$. The cells were treated with or without GYF-21 for $0.5 \mathrm{~h}$ and then stimulated with $20 \%$ conditioned medium (medium of BV-2 cells after stimulated with $0.5 \mu \mathrm{g} / \mathrm{ml}$ LPS for $24 \mathrm{~h}$ ) for $1.5 \mathrm{~h}$. The expressions of CD11b and CD62L on neutrophils which were gated by Ly- $6 \mathrm{G}$ were determined by flow cytometry.

\section{Activation and Proliferation Analysis of $\mathrm{CD}^{+} \mathrm{T}$ cells}

For $\mathrm{CD} 4^{+} \mathrm{T}$ cell activation assay, splenocytes were treated with or without GYF-21 for $0.5 \mathrm{~h}$. Then the cells were seeded in 24-well plate $\left(1 \times 10^{6}\right.$ cells $/$ well $)$ coated with anti-CD3e mAb $(4 \mu \mathrm{g} / \mathrm{ml})$ and stimulated with soluble anti-CD28 mAb $(2 \mu \mathrm{g} / \mathrm{ml})$ for $24 \mathrm{~h}$. The expressions of CD69 and CD25 on the surface of CD4 ${ }^{+} \mathrm{T}$ cells were determined by flow cytometry.

For $\mathrm{CD} 4^{+} \mathrm{T}$ cell proliferation assay, purified $\mathrm{CD} 4^{+} \mathrm{T}$ cells were treated with or without GYF-21 for $0.5 \mathrm{~h}$. Then the cells were seeded in 96-well plate $\left(2 \times 10^{5}\right.$ cells/well $)$ coated with anti-CD3e IgG $(4 \mu \mathrm{g} / \mathrm{ml})$ and stimulated with soluble anti-CD28 IgG $(2 \mu \mathrm{g} / \mathrm{ml})$ for $72 \mathrm{~h}$. Then $20 \mu \mathrm{l}$ of reagent in CCK-8 was added into each well and incubated for $4 \mathrm{~h}$. The culture plate was detected at the wavelength of $450 \mathrm{~nm}$ on a microplate reader. The OD values were used to indicate the levels of cell proliferation.

\section{Differentiation Assay of CD4 ${ }^{+} \mathrm{T}$ Cells}

Purified naive $\mathrm{CD} 4^{+} \mathrm{T}$ cells were treated with or without GYF-21 for $0.5 \mathrm{~h}$. Then the cells were seeded in 24 -well plate $\left(5 \times 10^{5}\right.$ cells/well) and stimulated to differentiate into Th1 and Th17 cells. For Th1 cell differentiation under skewing conditions, naive $\mathrm{CD}^{+}{ }^{+} \mathrm{T}$ cells were cultured with anti-CD3e mAb $(4 \mu \mathrm{g} / \mathrm{ml})$ plus anti-CD28 $\mathrm{mAb}(2 \mu \mathrm{g} / \mathrm{ml})$ in the presence of murine IL-12 $(10 \mathrm{ng} / \mathrm{ml})$, IFN- $\gamma(10 \mathrm{ng} / \mathrm{ml})$, anti-mouse IL-4 mAb $(10 \mu \mathrm{g} / \mathrm{ml})$. To generate Th17 cells under skewing conditions, naive $\mathrm{CD} 4^{+}$ $\mathrm{T}$ cells were cultured with anti-CD3e $\mathrm{mAb}(4 \mu \mathrm{g} / \mathrm{ml})$ plus antiCD28 $\mathrm{mAb}(2 \mu \mathrm{g} / \mathrm{ml})$ in the presence of murine IL-6 $(20 \mathrm{ng} / \mathrm{ml})$, TGF- $\beta$ ( $5 \mathrm{ng} / \mathrm{ml})$, anti-IFN- $\gamma \mathrm{mAb}(10 \mu \mathrm{g} / \mathrm{ml})$, anti-IL- $4 \mathrm{mAb}$ $(10 \mu \mathrm{g} / \mathrm{ml})$. Four days after priming, cells were washed and restimulated with PMA $(50 \mathrm{ng} / \mathrm{ml})$ and ionomycin $(1 \mu \mathrm{M})$ for $6 \mathrm{~h}$ and with monensin for last $4 \mathrm{~h}$, and the frequencies of Th1 and Th17 cells in live cells were determined by flow cytometry.

\section{Analysis of the Activation, Proliferation, and IFN- $\gamma$ Secretion of $\mathrm{CD}^{+}{ }^{+} \mathrm{T}$ Cells}

For $\mathrm{CD} 8^{+} \mathrm{T}$ cells activation assay, splenocytes were treated with or without GYF-21 for $0.5 \mathrm{~h}$. Then the cells were seeded in 24 -well plate $\left(1 \times 10^{6}\right.$ cells/well $)$ coated with anti-CD3e mAb $(4 \mu \mathrm{g} / \mathrm{ml})$ and stimulated with soluble anti-CD28 mAb $(2 \mu \mathrm{g} / \mathrm{ml})$ for $24 \mathrm{~h}$. The expressions of CD69 and CD25 on the surface of CD8 ${ }^{+} \mathrm{T}$ cells were determined by flow cytometry.

For $\mathrm{CD}^{+} \mathrm{T}$ cell proliferation and interferon- $\gamma$ (IFN- $\gamma$ ) secretion assays, purified $\mathrm{CD}^{+} \mathrm{T}$ cells were treated with or without GYF-21 for $0.5 \mathrm{~h}$. Then the cells were seeded in 96-well plate $\left(3 \times 10^{5}\right.$ cells/well) coated with anti-CD3e IgG $(4 \mu \mathrm{g} / \mathrm{ml})$ and stimulated with soluble anti-CD28 IgG $(2 \mu \mathrm{g} / \mathrm{ml})$ for $72 \mathrm{~h}$. Subsequently, $100 \mu \mathrm{l}$ medium was collected from each well and the level of IFN- $\gamma$ in the medium was determined by ELISA. Then $10 \mu \mathrm{l}$ of reagent in CCK- 8 was added into each well and incubated for $4 \mathrm{~h}$. The culture plate was detected at the wavelength of $450 \mathrm{~nm}$ on a microplate reader. The OD values were used to indicate the levels of cell proliferation.

\section{Western Blot Analysis}

BV-2 cells were seeded in 6-well plate $\left(2 \times 10^{5}\right.$ cells/well $)$. After incubated for $24 \mathrm{~h}$, the cells were treated with or without 
A

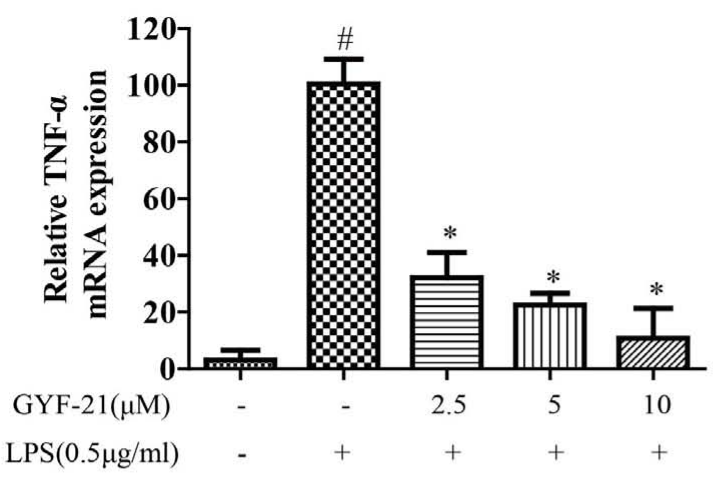

B

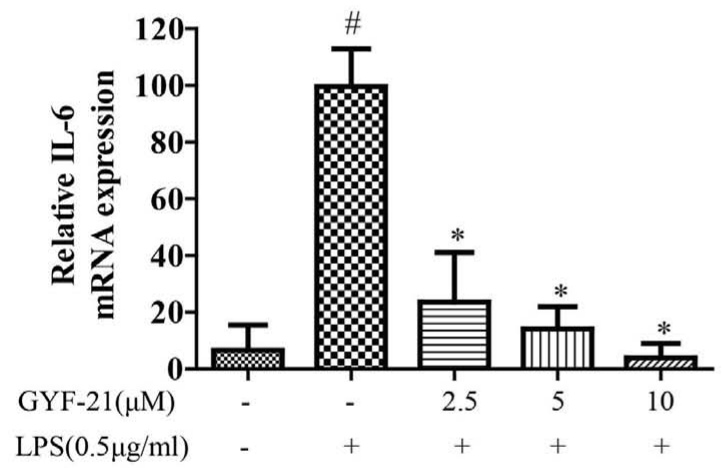

C

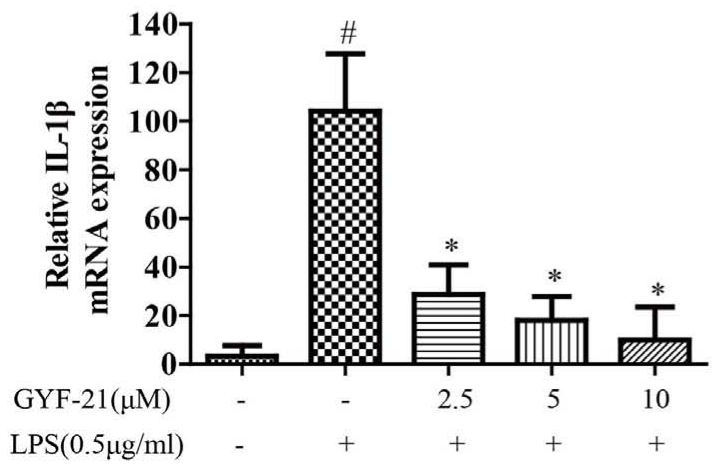

D

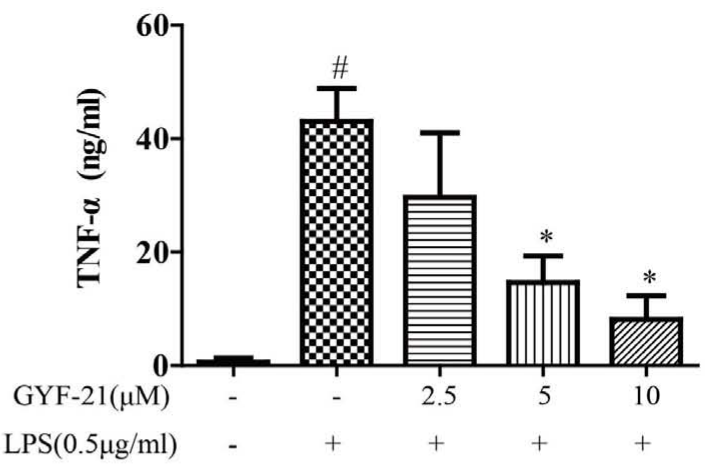

E

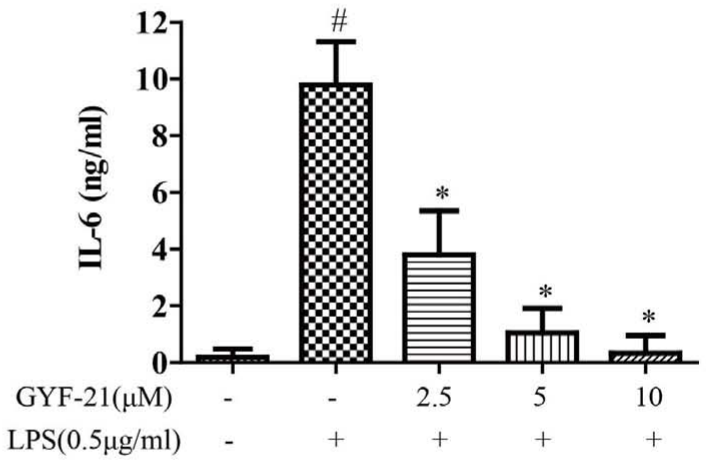

$\mathbf{F}$

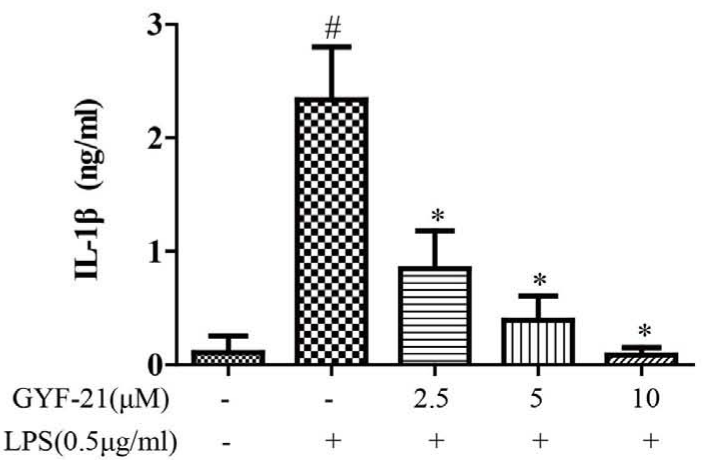

FIGURE 3 | Effects of GYF-21 on the expression of pro-inflammatory cytokines by microglia. BV-2 cells were pretreated with various concentrations of GYF-21 for $0.5 \mathrm{~h}$ and then stimulated with LPS $(0.5 \mu \mathrm{g} / \mathrm{ml})$ for $6 \mathrm{~h}$ (RT-PCR) or $12 \mathrm{~h}$ (ELISA). The mRNA transcription of TNF- $\alpha$, IL-6, and IL-1 $\beta$ was determined by RT-PCR (A-C). The levels of TNF- $\alpha$, IL-6, and IL-1 $\beta$ in the supernatants were determined by ELISA (D-F). Data are representative of three independent experiments. ${ }^{\#} P<0.05$ vs. Vehicle, ${ }^{*} P<0.05$ vs. LPS.

GYF-21 for $0.5 \mathrm{~h}$ and then stimulated with LPS for $30 \mathrm{~min}$ or $3 \mathrm{~h}$. After stimulation, the cells were collected with cell scraper and total cell proteins were extracted with RIPA lysis buffer. Then proteins were separated by $10 \%$ SDS-PAGE and transferred to polyvinylidenedifluoride membranes. The membranes were blocked in $5 \%$ skim milk for $1 \mathrm{~h}$ and incubated overnight at $4^{\circ} \mathrm{C}$ with antibodies against p65, I-кB, p38, ERK1/2, JNK, STAT1, STAT3 and their phosphorylated forms. Membranes were rinsed and incubated with horseradish peroxide-conjugated secondary antibodies for $2 \mathrm{~h}$ at room temperature, then rinsed again. Bands were visualized by ECL reagents on ImageQuant ${ }^{\text {TM }}$ LAS4000 (GE Healthcare Bio-Sciences, Pittsburgh, PA, United States).

\section{Statistical Analysis}

All quantitative data were expressed as mean \pm standard deviation (SD) of values from three independent experiments. Statistical analyses were performed with GraphPad Prism 5.0. One-way ANOVA followed by Dunnett's test was used to determine statistical significance. A $P$-value less than 0.05 was considered to be statistically significant. 


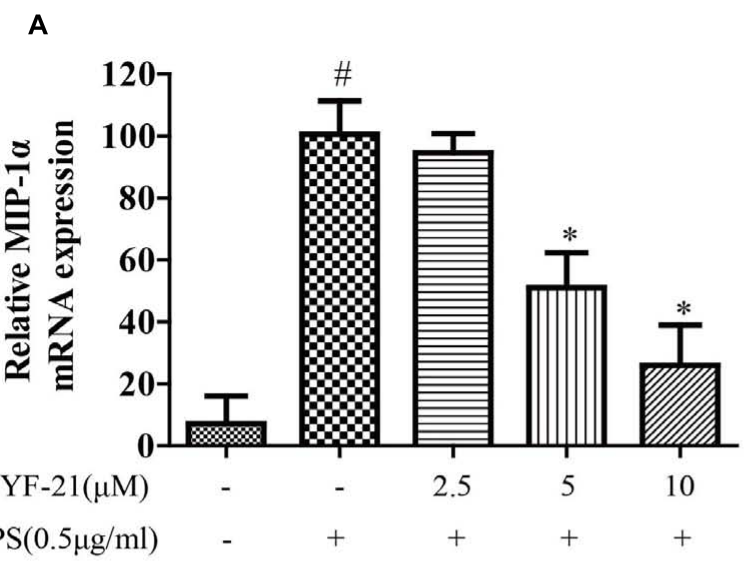

B

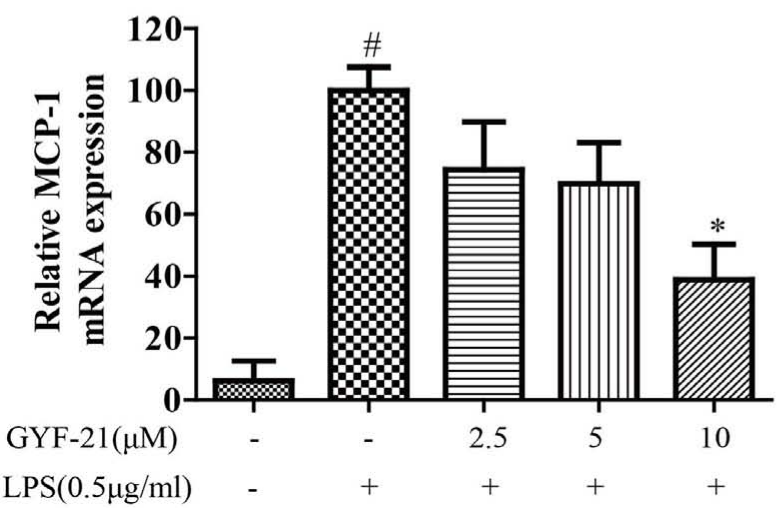

C

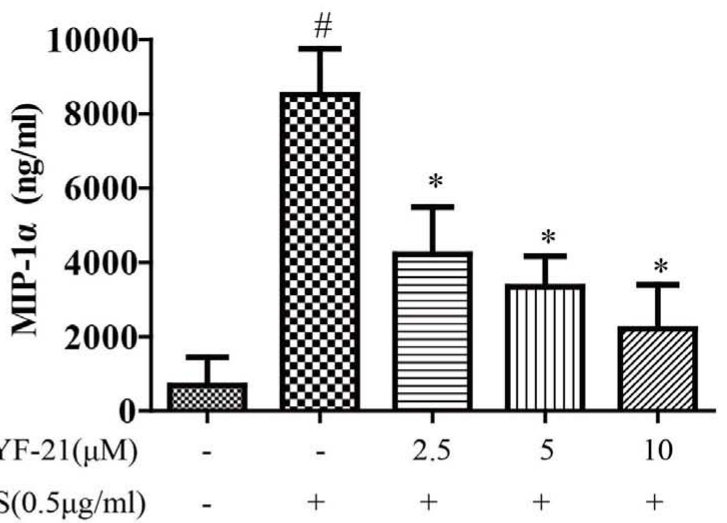

D

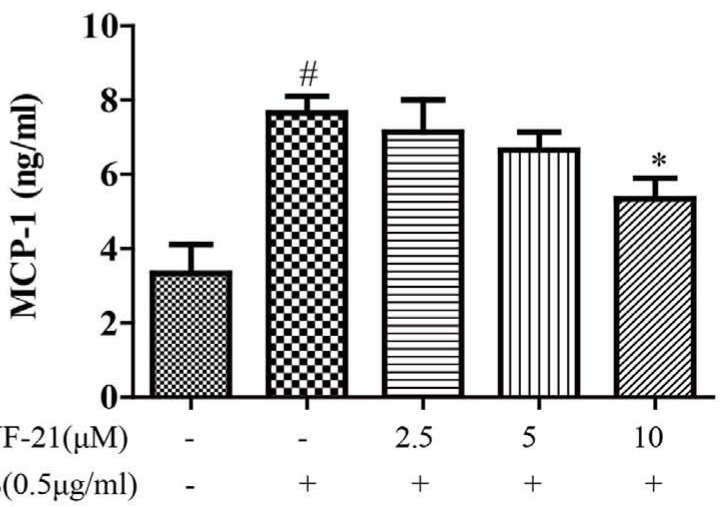

FIGURE 4 | Effects of GYF-21 on the expression of chemokines by microglia. BV-2 cells were pretreated with various concentrations of GYF-21 for $0.5 \mathrm{~h}$ and then stimulated with LPS $(0.5 \mu \mathrm{g} / \mathrm{ml})$ for $6 \mathrm{~h}$ (RT-PCR) or $12 \mathrm{~h}$ (ELISA). The mRNA transcription of MIP-1 $\alpha$ and MCP-1 was determined by RT-PCR (A,B). The levels of MIP-1 $\alpha$ and MCP-1 in the supernatants were determined by ELISA (C,D). Data are representative of three independent experiments. ${ }^{\#} P<0.05$ vs. Vehicle, $* P<0.05$ vs. LPS.

\section{RESULTS}

\section{Structural Identification and Purity Analysis of GYF-21}

The structure of GYF-21 was determined to be (1aS, $2 S$, $3 S, 7 \mathrm{~b} R)$-2, 3-dihydroxy-5-(4-methoxyphenethyl)-2, 3-dihydro1aH-oxireno [2, 3-f] chromen-7 (7b H)-one. ${ }^{1} \mathrm{H} \mathrm{NMR}\left(\mathrm{CD}_{3} \mathrm{OD}\right.$, $500 \mathrm{MHz}) \delta: 3.97(1 \mathrm{H}, \mathrm{d}, J=4.0 \mathrm{~Hz}, \mathrm{H}-5), 3.74(1 \mathrm{H}, \mathrm{d}$, $J=1.0 \mathrm{~Hz}, \mathrm{H}-6), 3.89(1 \mathrm{H}, \mathrm{d}, J=6.5,1.0 \mathrm{~Hz}, \mathrm{H}-7), 4.37$ $(1 \mathrm{H}, \mathrm{d}, J=7.0 \mathrm{~Hz}, \mathrm{H}-8), 7.16\left(2 \mathrm{H}, \mathrm{d}, J=8.5 \mathrm{~Hz}, \mathrm{H}-2^{\prime}\right.$, $\left.6^{\prime}\right), 6.85\left(2 \mathrm{H}, \mathrm{d}, J=8.5 \mathrm{~Hz}, \mathrm{H}-3^{\prime}, 5^{\prime}\right), 6.25(1 \mathrm{H}, \mathrm{s}, \mathrm{H}-3)$, $3.71\left(3 \mathrm{H}, \mathrm{s}, 4^{\prime}-\mathrm{OCH}_{3}\right), 2.89\left(4 \mathrm{H}, \mathrm{m}, \mathrm{H}-7^{\prime}, 8^{\prime}\right) .{ }^{13} \mathrm{C} \mathrm{NMR}$ (DMSO- $\left.d_{6}, 125 \mathrm{MHz}\right) \delta: 169.2$ (C-2), 113.6 (C-3), 180.0 (C-4), 49.2 (C-5), 55.0 (C-6), 70.5 (C-7), 68.2 (C-8), 159.1 (C-9), 120.4 (C-10), $131.6\left(\mathrm{C}-1^{\prime}\right), 129.2\left(\mathrm{C}-2^{\prime}\right), 113.8\left(\mathrm{C}-3^{\prime}\right), 157.7$

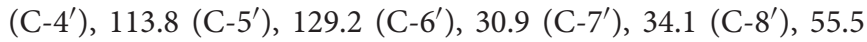
$\left(4^{\prime}-\mathrm{OCH}_{3}\right)$. ESI-MS: $m / z$ : $331[\mathrm{M}+\mathrm{H}]^{+}$, molecular formula: $\mathrm{C}_{18} \mathrm{H}_{18} \mathrm{O}_{6}$. All spectral data were in agreement with literature data (Wu et al., 2012). The purity of GYF-21 was greater than 94\% according to HPLC analysis on LCMS-IT-TOF platform (Figure 1B).

\section{Cytotoxicity of GYF-21 on Microglia and Splenocytes}

In order to investigate the immunosuppressive effects of GYF-21 under doses without cytotoxicity, the cytotoxicity of GYF-21 on microglia and splenocytes was evaluated with CCK-8. The results (Figure 2) showed that GYF-21 had no cellular toxicity on BV-2 cells at the concentration up to $25 \mu \mathrm{M}$ and on splenocytes at the concentration up to $2 \mu \mathrm{M}$.

\section{Inhibitory Effects of GYF-21 on the Expression of Cytokines and Chemokines by Microglia}

The overproductions of pro-inflammatory cytokines and chemokines by microglia, such as TNF- $\alpha$, IL-6, IL-1 $\beta$, MCP-1, and MIP- $1 \alpha$, play important roles in the pathogenesis of MS (Ogura et al., 2008; Starossom et al., 2012). To investigate the effects of GYF-21 on innate immune cells, the effects of GYF-21 on the expression of cytokines and chemokines by LPS induced microglia were detected firstly. As shown in Figures 3, 4, compared to the control group, the mRNA transcription 


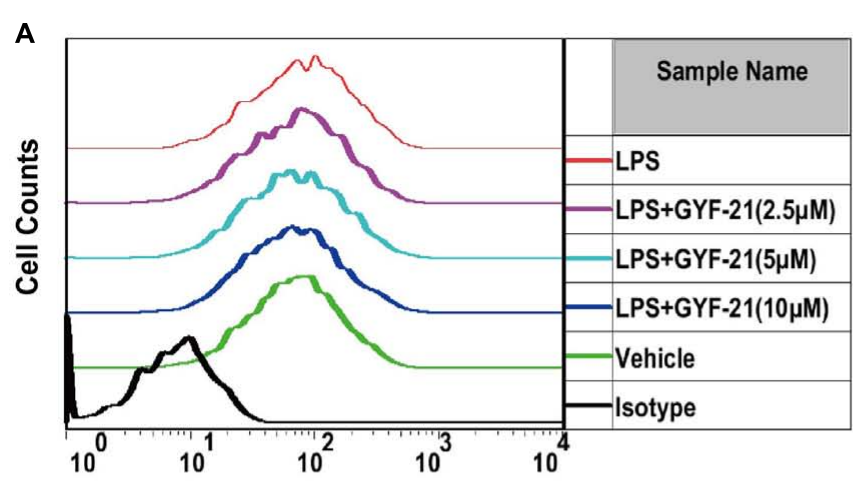

FITC-CD80

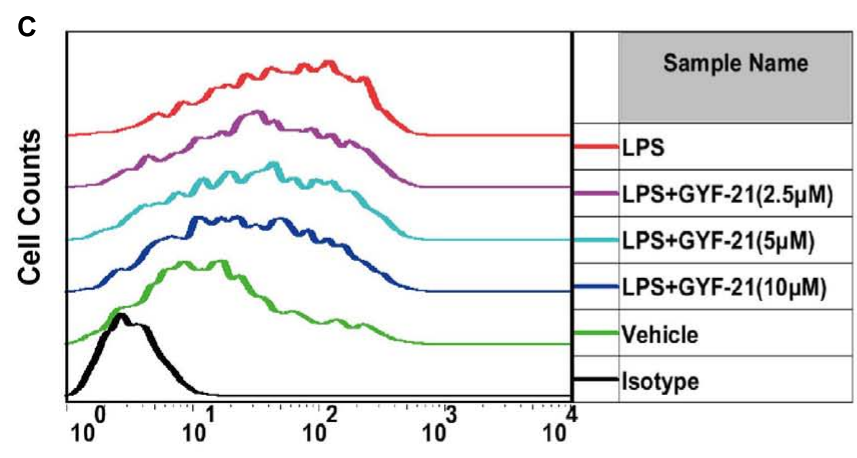

PE-CD86

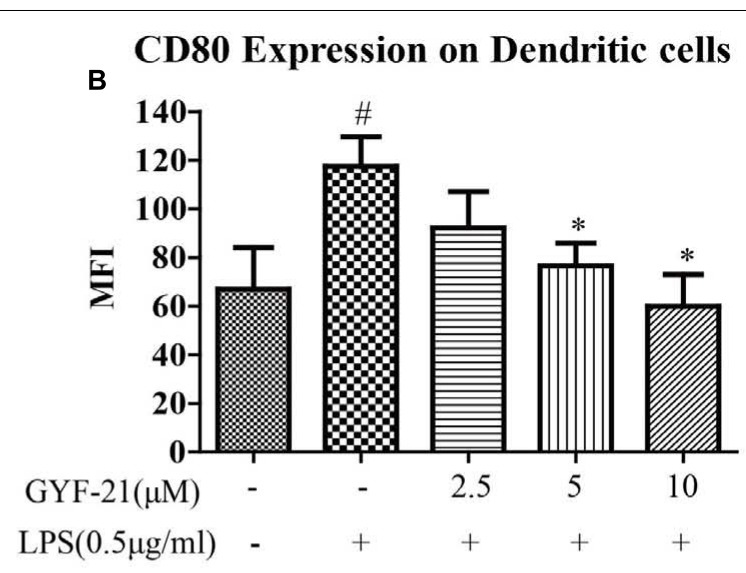

CD86 Expression on Dendritic cells

D

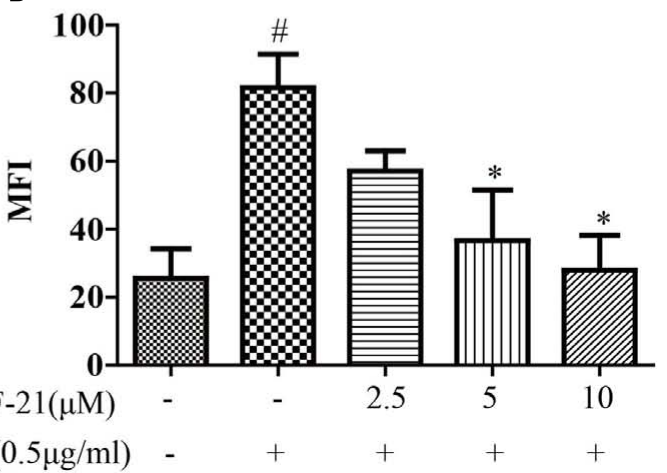

FIGURE 5 | Effects of GYF-21 on the activation of dendritic cells. BMDC were pretreated with various concentrations of GYF-21 for $0.5 \mathrm{~h}$ and then stimulated with LPS for $24 \mathrm{~h}$. The expression of CD80 (A,B) and CD86 (C,D) on BMDC (CD11 ${ }^{+}$cells) were determined by flow cytometry. Data are representative of three independent experiments. ${ }^{\#} P<0.05$ vs. Vehicle, ${ }^{*} P<0.05$ vs. LPS.

and protein secretion of pro-inflammatory cytokines and chemokines, TNF- $\alpha$, IL-6, IL-1 $\beta$, MCP-1, and MIP-1 $\alpha$, were both dramatically elevated in LPS-treated group. However, GYF-21 intensively inhibited the expressions of TNF- $\alpha$, IL- 6 , and IL- $1 \beta$ in a dose-dependent manner (inhibition rates of $60-99 \%$ ) and moderately suppressed the expressions of MCP-1and MIP- $1 \alpha$ (inhibition rate of 40 or $80 \%$ for high dose treatment).

\section{Effects of GYF-21 on the Activation of Dendritic Cells}

Dendritic cells are professional antigen presenting cells and link the innate and adaptive immune system. When dendritic cells are activated, CD80 and CD86 on dendritic cells upregulated rapidly and provide costimulatory signal necessary for $\mathrm{T}$ cell activation and survival (Wu and Laufer, 2007; Comabella et al., 2010; Nuyts et al., 2013). After demonstrated the inhibitory effects of GYF-21 on the activation of microglia, we further investigated the effects of GYF-21 on the activation of dendritic cells. The results (Figure 5) showed that GYF-21 significantly suppressed upregulation of CD80 and CD86 on CD11 $\mathrm{c}^{+}$dendritic cells in a dose-dependent manner (inhibition rates of 40-80\%).

\section{Effects of GYF-21 on the Activation of Neutrophils}

Neutrophils are the most abundant type of granulocytes and the most abundant type of white blood cells in most mammals. They also form an essential part in the pathogenesis of MS (Steinbach et al., 2013). After discovered the inhibitory effects of GYF-21 on the activation of microglia and dendritic cells, we also investigated the effects of GYF-21 on the activation of neutrophils. The results (Figure 6) showed that GYF-21 slightly suppressed conditioned medium-induced $\mathrm{CD} 11 \mathrm{~b}$ upregulation and CD62L shedding on the Ly- $6 \mathrm{G}^{+}$neutrophils in a dosedependent manner (inhibition rates of $15-30 \%$ ).

\section{Effects of GYF-21 on the Activation of NF- $\kappa B$, MAPK, and STAT1/3 Signaling} Pathways in Microglia

It is well-known that nuclear factor kappa B (NF-кB), mitogenactivated protein kinase (MAPK), and signal transducer and activator of transcription 1/3 (STAT1/3) signaling pathways play critical roles in the function regulation of innate immune cells (Tak and Firestein, 2001; Li and Verma, 2002; Shuai and Liu, 

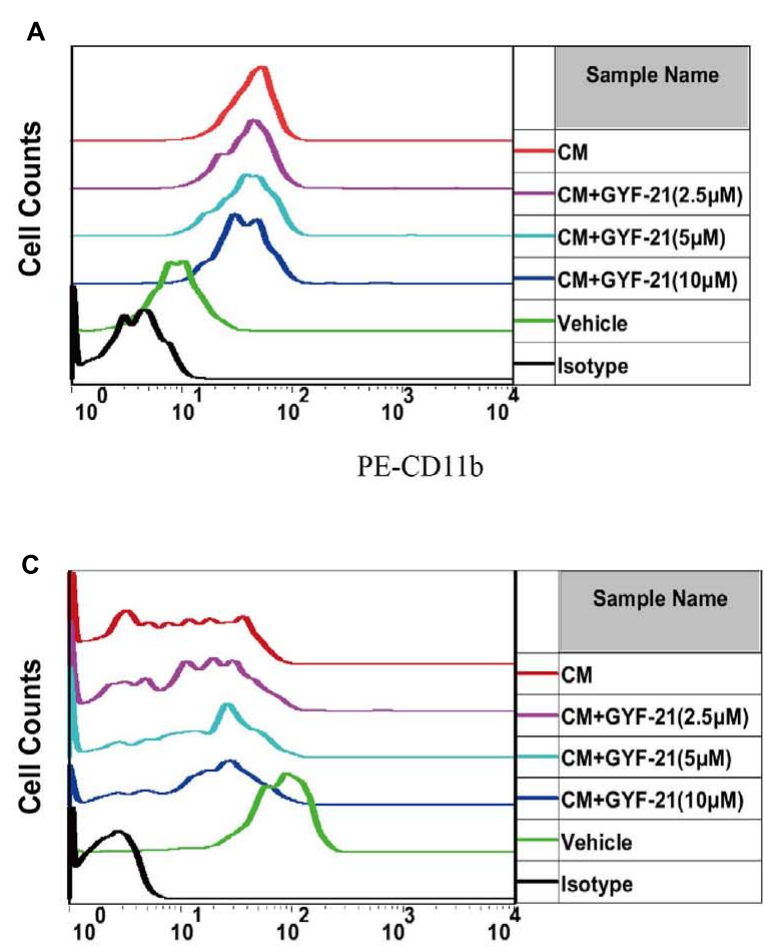

FITC-CD62L

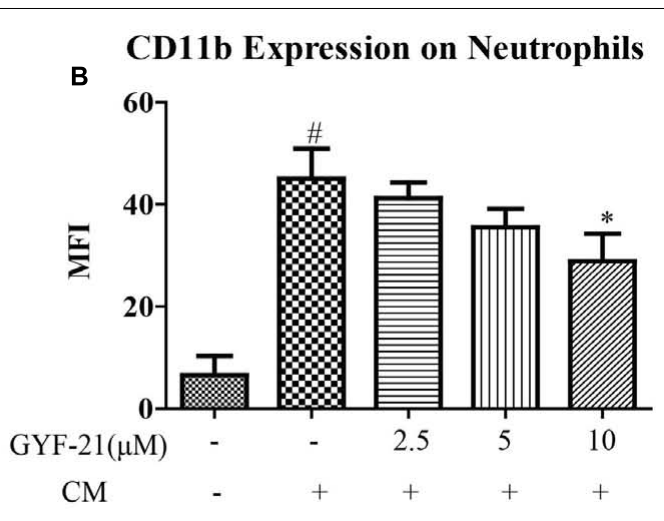

DD62L Expression on Neutrophils

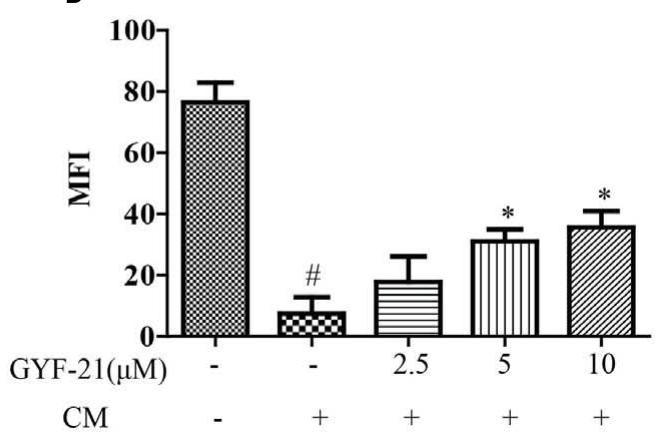

FIGURE 6 | Effects of GYF-21 on the activation of neutrophils. BM cells were pretreated with various concentrations of GYF-21 for $0.5 \mathrm{~h}$ and then stimulated with conditioned medium for $1.5 \mathrm{~h}$. The levels of CD11b (A,B) and CD62L (C,D) on neutrophils (Ly-6G+ cells) were determined by flow cytometry. Data are representative of three independent experiments. ${ }^{\#} P<0.05$ vs. Vehicle, ${ }^{*} P<0.05$ vs. CM.

2003; Zhang and Dong, 2005; Miklossy et al., 2013; Schwartz et al., 2015). In order to reveal the mechanism of GYF-21 inhibiting the activation of innate immune cells, we investigated the effects of GYF-21 on the activation of NF- $\kappa$ B, MAPK and STAT1/3 signaling pathways in microglia induced by LPS. The results (Figure 7 ) showed that highly phosphorylation of p65, I-кB, p38, ERK1/2, JNK, STAT1, and STAT3 was observed in LPS-induced BV-2 cells and GYF-21 significantly inhibited the phosphorylation of STAT1/3, p65 and I- $\kappa$ B in a dosedependent manner rather than the phosphorylation of $\mathrm{p} 38$, ERK1/2, and JNK.

\section{Effects of GYF-21 on the Activation and Proliferation of $\mathrm{CD}^{+}{ }^{+} \mathrm{T}$ Cells}

After discovered the inhibitory effects of GYF-21 on the activation of multiple innate immune cells via suppressing STAT1/3 and NF- $\mathrm{B}$ signaling pathways, we furtherly investigated the effects of GYF-21 on adaptive immunity in virtue of important roles that STAT1/3 and NF- $\kappa$ B signaling pathways play in adaptive immunity. Firstly, we investigated the effects of GYF-21 on the activation and proliferation of $\mathrm{CD} 4^{+} \mathrm{T}$ cells. The results (Figure 8) showed that GYF-21 didn't suppress upregulation of CD69 and CD25 on CD4 ${ }^{+} \mathrm{T}$ cells and proliferation of $\mathrm{CD}^{+} \mathrm{T}$ cells stimulated by anti-mouse CD3e and CD28 IgG.

\section{Effects of GYF-21 on the Differentiation of CD4 ${ }^{+}$T Cells}

$\mathrm{CD} 4^{+} \mathrm{T}$ cells are a type of $\mathrm{T}$ cell that plays central role in the pathogenesis of MS. In the presence of cytokines produced by cells of innate immunity, naive $\mathrm{CD} 4^{+} \mathrm{T}$ cells differentiate into helper $\mathrm{T}$ cells subset with different functions and cytokine profiles. Three main helper $\mathrm{T}$ cell subsets, Th1, Th2, and Th17, were described. Previous studies demonstrated that both Th1 cells and Th17 cells were able to independently induce MS. After determined the inhibitory effects of GYF-21 on the activation of STAT $1 / 3$ signaling pathways which play major roles in promoting $\mathrm{CD}^{+}{ }^{+} \mathrm{T}$ cells to differentiate into Th1 and Th17 cells respectively, we further investigated the effects of GYF-21 on the differentiation of naive $\mathrm{CD} 4^{+} \mathrm{T}$ cells. The results (Figure 9) showed that GYF-21 significantly inhibited the differentiation of naive $\mathrm{CD} 4^{+} \mathrm{T}$ cells into Th1 and Th17 cells in a dose-dependent manner (inhibition rates of $30-75 \%$ ).

\section{Effects of GYF-21 on the Activation, Proliferation, and IFN $-\gamma$ Secretion of $\mathrm{CD}^{+}$T Cells}

The mechanisms studied in MS focus on the activity of myelinspecific $\mathrm{CD}^{+}{ }^{+} \mathrm{T}$ cells. However, $\mathrm{CD} 8^{+} \mathrm{T}$ cells are also strongly implicated in the pathogenesis of MS (Ji et al., 2013). After 
A

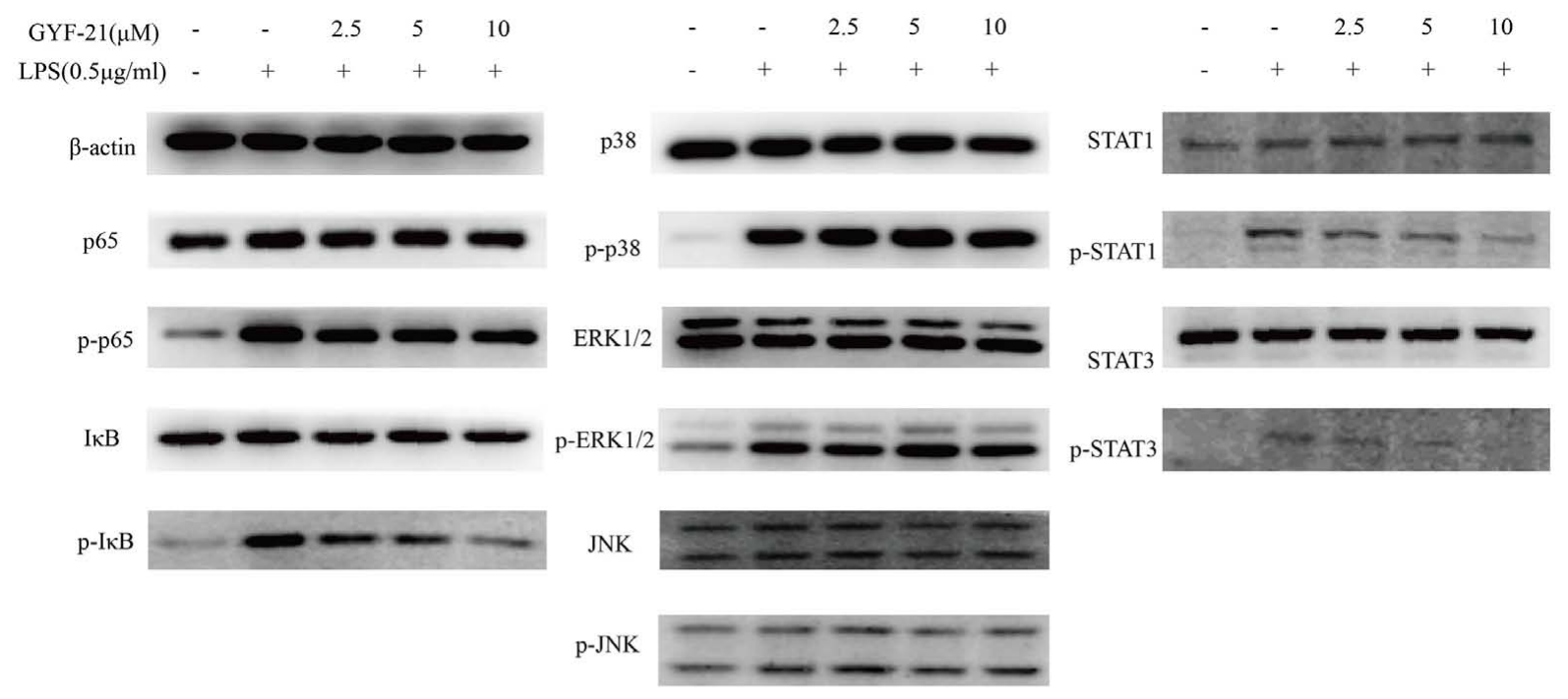

B
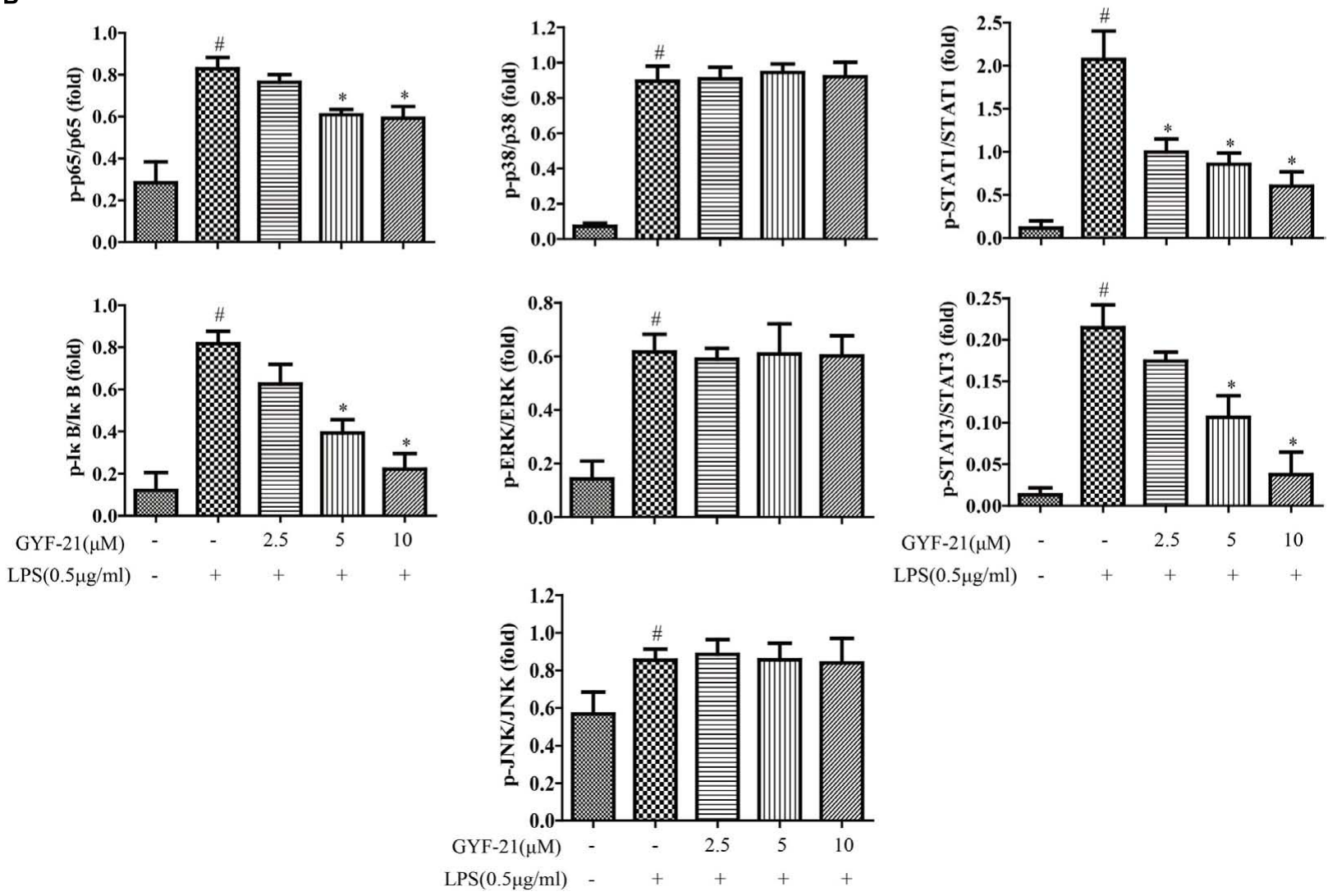

FIGURE 7 | Effects of GYF-21 on the activation of NF-KB, MAPK, and STAT1/3 signaling pathways. BV-2 cells were pretreated with various concentrations of GYF-21 for $0.5 \mathrm{~h}$ and then stimulated with LPS $(0.5 \mu \mathrm{g} / \mathrm{ml})$ for 0.5 or $3 \mathrm{~h}$. The expressions of p65, l-kB, p38, ERK1/2, JNK, STAT1, STAT3 and their phosphorylated forms were determined by western blot (A,B). A typical result in three independent experiments is shown. ${ }^{\#} P<0.05$ vs. Vehicle, ${ }^{*} P<0.05$ vs. LPS alone.

determined the inhibitory effects of GYF-21 on the differentiation of $\mathrm{CD}^{+} \mathrm{T}$ cells into Th1 cells, it's meaningful to further investigate the effects of GYF-21 on $\mathrm{CD}^{+} \mathrm{T}$ cells. Then we determined the effects of GYF-21 on the activation, proliferation, and IFN- $\gamma$ secretion of $\mathrm{CD}^{+}{ }^{+} \mathrm{T}$ cells. The results (Figure 10) showed that GYF-21 slightly suppressed upregulation of CD69 
A

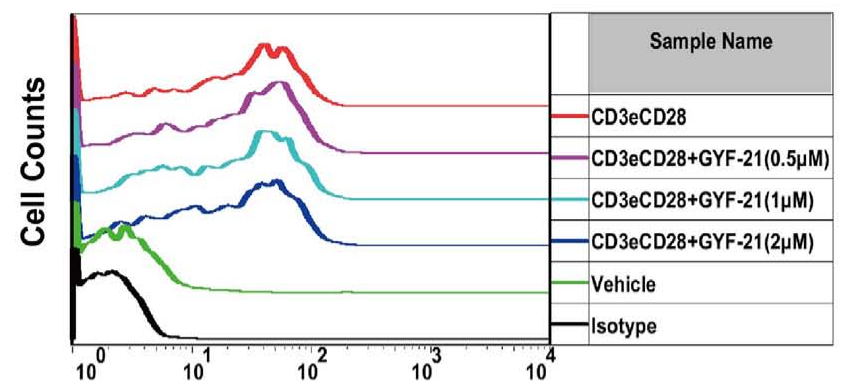

PE-CD69

C

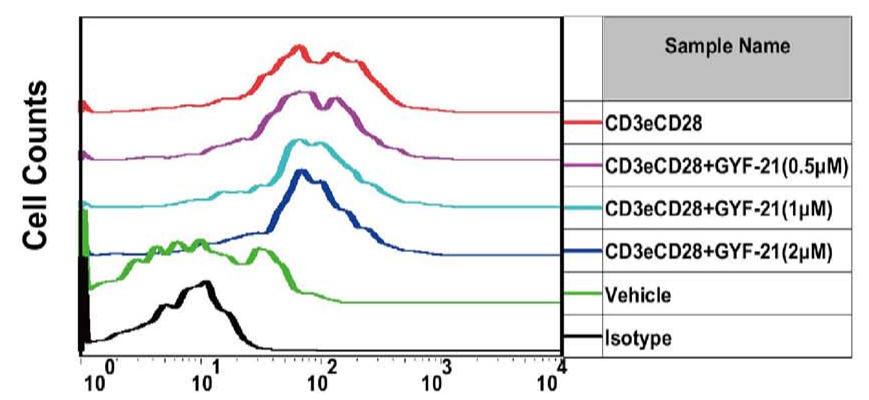

FITC-CD25
B CD69 Expression on $\mathrm{CD}^{+} \mathrm{T}$ cells

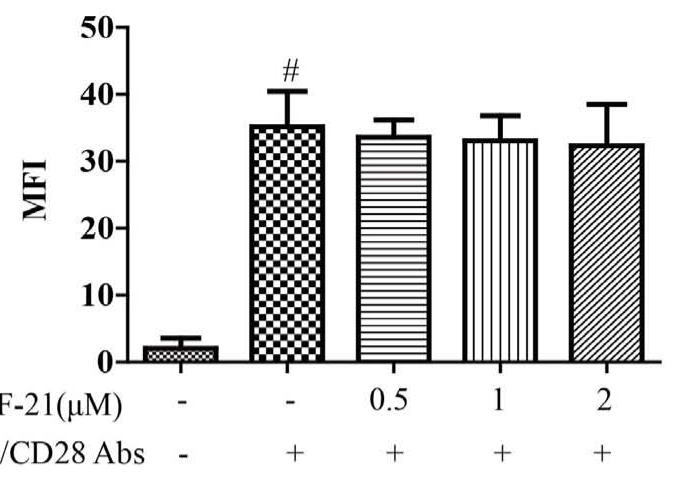

D CD25 Expression on $\mathrm{CD4}^{+} \mathrm{T}$ cells

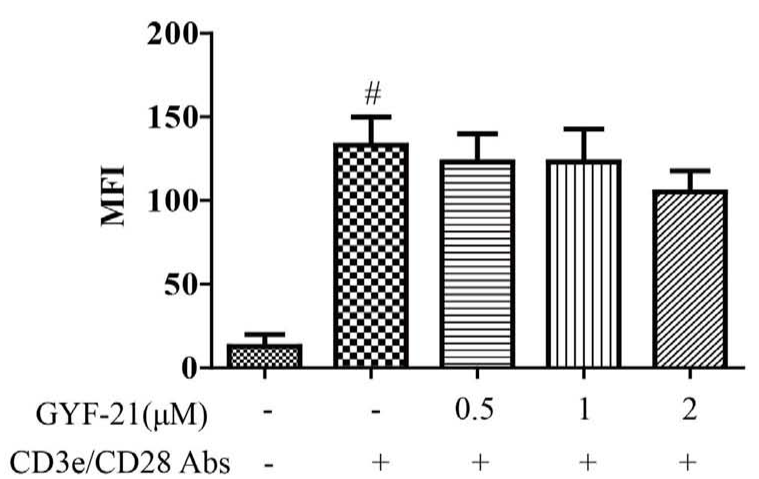

E

Proliferation of $\mathrm{CD}^{+} \mathrm{T}$ cells

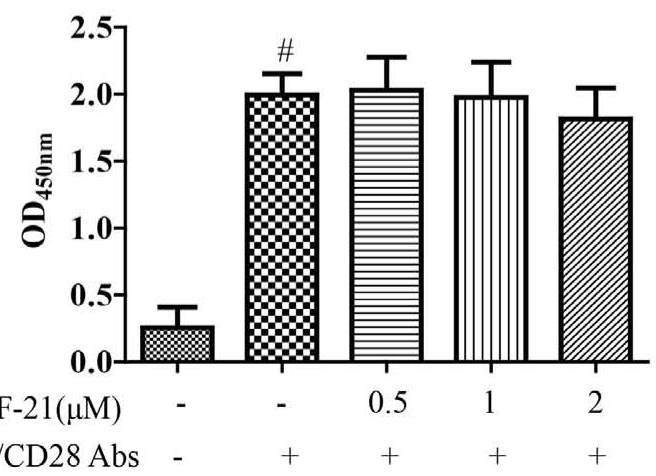

FIGURE 8 | Effects of GYF-21 on the activation and proliferation of CD4+ T cells. Splenocytes were pretreated with or without GYF-21 for $0.5 \mathrm{~h}$. Then the cells were seeded in 24-well plate $\left(1 \times 10^{6}\right.$ cells/well) coated with anti-mouse CD3e lgG $(4 \mu \mathrm{g} / \mathrm{mll})$, and stimulated with anti-mouse CD28 lgG $(2 \mu \mathrm{g} / \mathrm{ml})$ for $24 \mathrm{~h}$. The levels of CD69 and CD25 on CD $4^{+} T$ cells were determined by flow cytometry (A-D). CD4 ${ }^{+} T$ cells were purified by negative magnetic bead isolation kit and pretreated with or without GYF-21 for $0.5 \mathrm{~h}$. Then the cells were seeded in 96-well plate $\left(2 \times 10^{5} \mathrm{cells} /\right.$ well) coated with anti-mouse CD3e lgG (4 $\left.\mu \mathrm{g} / \mathrm{ml}\right)$ and stimulated with anti-mouse CD28 lgG $(2 \mu \mathrm{g} / \mathrm{ml})$ for $72 \mathrm{~h}$. CD4 ${ }^{+}$T cell proliferation was determined with CCK-8 (E). Data are representative of three independent experiments. ${ }^{\#} P<0.05$ vs. Vehicle, ${ }^{*} P<0.05$ vs. CD3e/CD28 Abs.

and $\mathrm{CD} 25$ on $\mathrm{CD}^{+} \mathrm{T}$ cells and proliferation of $\mathrm{CD}^{+} \mathrm{T}$ cells stimulated by anti-mouse CD3e and CD28 IgG (inhibition rates of $15-30 \%$ for high dose treatment). In addition, GYF-21 moderately inhibited IFN- $\gamma$ secretion of CD8 ${ }^{+} \mathrm{T}$ cells in a dosedependent manner (inhibition rates of $0-60 \%$ ).

\section{DISCUSSION}

Microglia, dendritic cells, and neutrophils are major innate immune cells that play important roles in pathogenesis of MS. Microglia are resident tissue macrophages located in the CNS. 


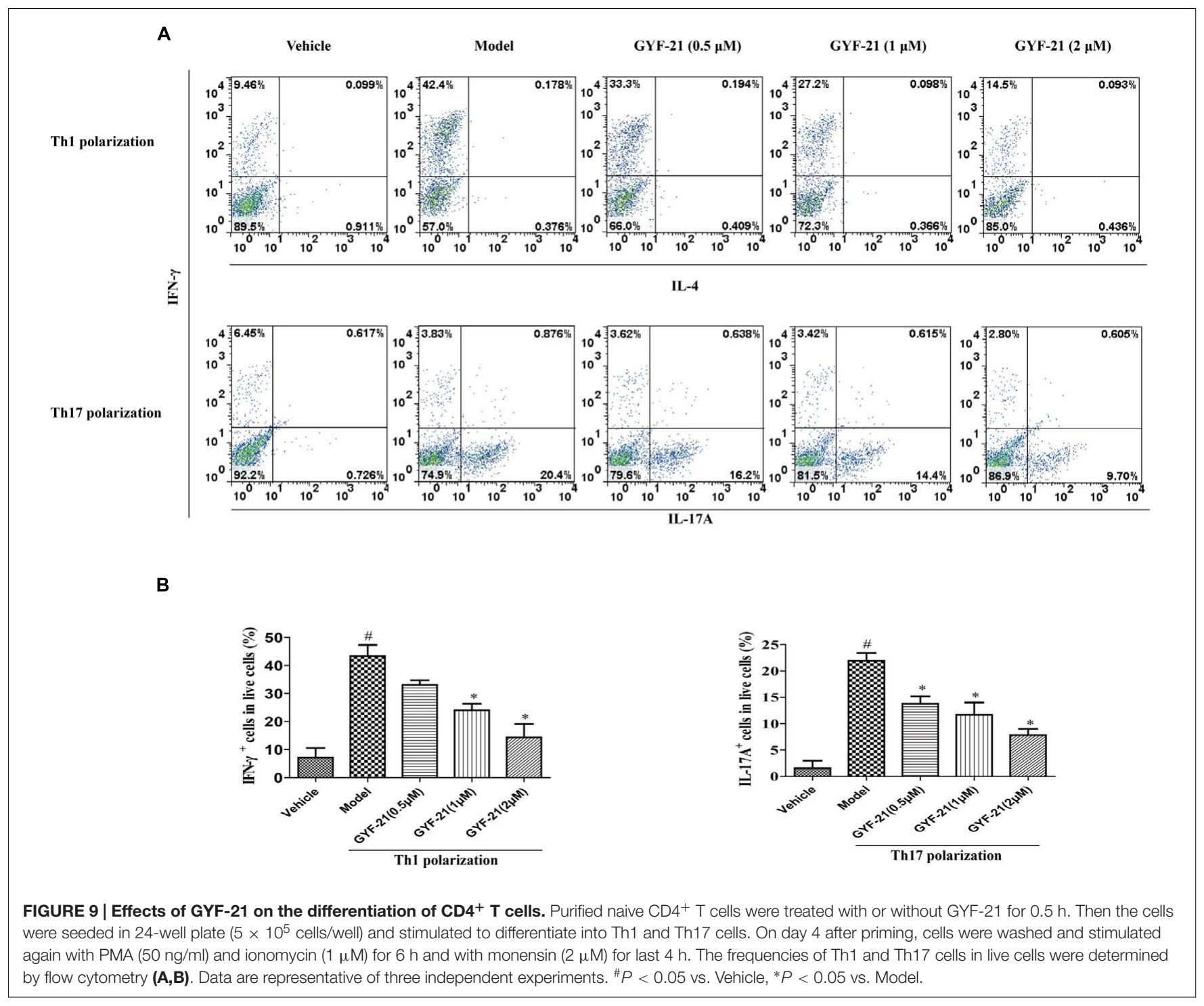

The interactions between microglia and $\mathrm{T}$ cells are crucial in MS pathobiology (Starossom et al., 2012; Goldmann and Prinz, 2013; Strachan-Whaley et al., 2014). Dendritic cells are the primary antigen presenting cells directing $\mathrm{T}$ cell function and are extremely important in directing the immune pathology characteristic of MS (Wu and Laufer, 2007; Comabella et al., 2010; Nuyts et al., 2013). Neutrophils are required for the maturation of myeloid cells into professional APCs and local restimulation of myelin-specific T cells (Jaillon et al., 2013; Steinbach et al., 2013).

In this study, we firstly determined the inhibitory effects of GYF-21 on the activation of microglia cell line BV-2 induced by LPS. The results showed that GYF-21 intensively inhibited the expression of pro-inflammatory cytokines, TNF- $\alpha$, IL- 6 and IL-1 $\beta$, and moderately suppressed the expression of chemokines, MCP-1 and MIP-1 $\alpha$. After demonstrated the inhibitory activity of GYF-21 on the activation of microglia, we investigated the effects of GYF-21 on the activation of dendritic cells and neutrophils. The results showed that GYF-21 significantly inhibited upregulation of costimulatory molecules, CD80 and CD86, on dendritic cells. In addition, GYF-21 also slightly inhibited upregulation of CD11b and shedding of CD62L on neutrophils. These data revealed the inhibitory effects of GYF-21 on the activation of microglia, dendritic cells and neutrophils with different strengths, and suggested that GYF-21 could significantly inhibit innate immunity with combined inhibitory effects on above innate immune cells.

NF- $\mathrm{B}, \mathrm{MAPK}$, and STAT1/3 signaling pathways play key roles in signal transduction during innate immune responses (Tak and Firestein, 2001; Li and Verma, 2002; Shuai and Liu, 2003; O'Shea et al., 2004; Zhang and Dong, 2005; Loo et al., 2006; Schulz et al., 2011; Miklossy et al., 2013; Schwartz et al., 2015). After revealed the inhibitory effects of GYF-21 on the activation of innate immunity, we investigated its mechanism by monitoring the activation of NF-кB, MAPK, and STAT $1 / 3$ signaling pathways in BV-2 cells induced by LPS. The results showed that GYF-21 

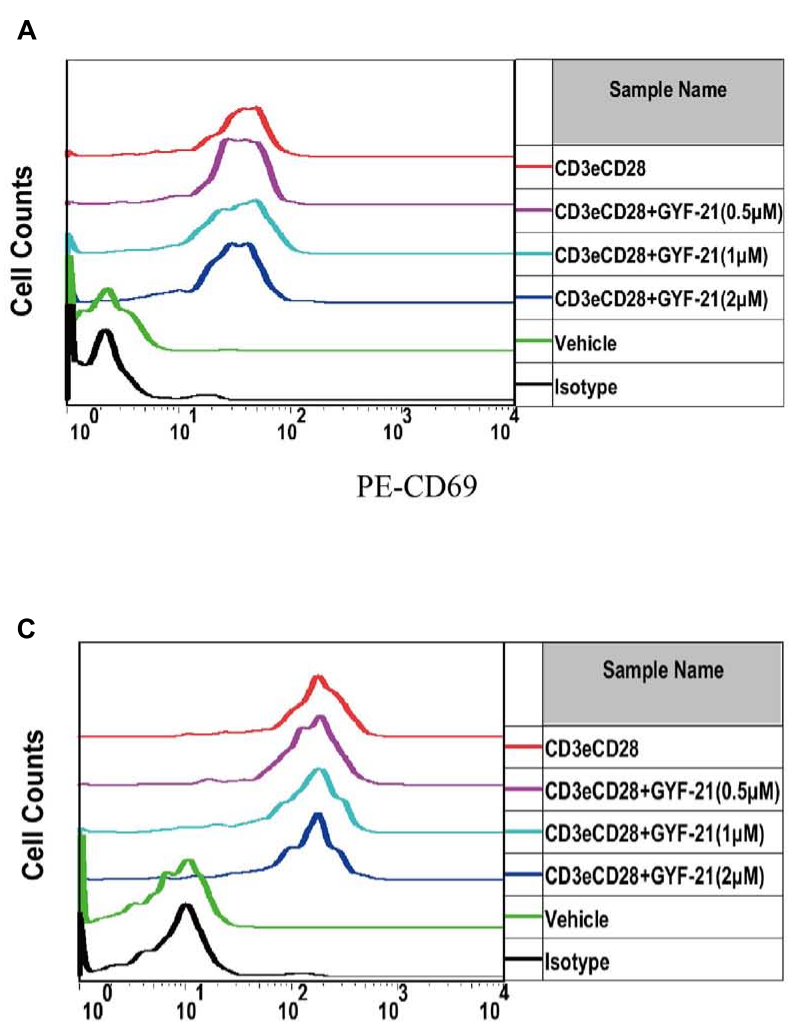

PE-CD25

E

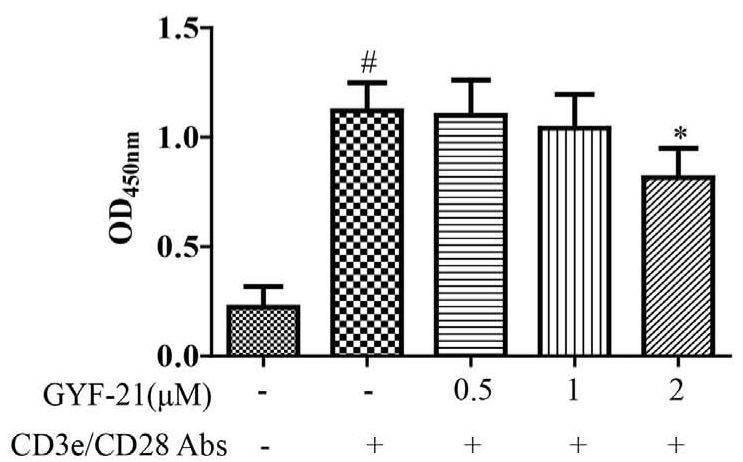

B CD69 Expression on $\mathrm{CD8}^{+} \mathrm{T}$ cells

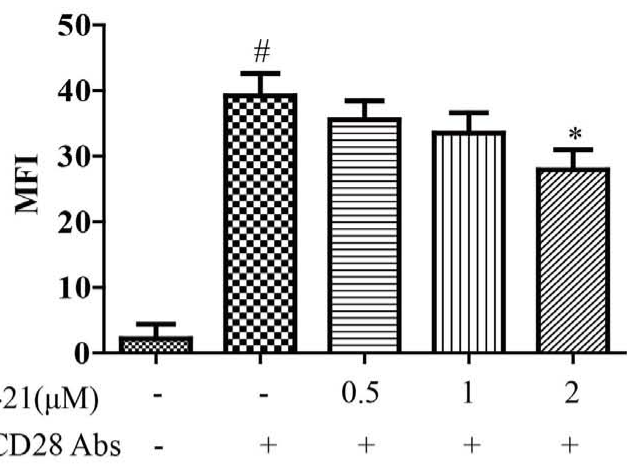

D CD25 Expression on $\mathrm{CD8}^{+} \mathrm{T}$ cells

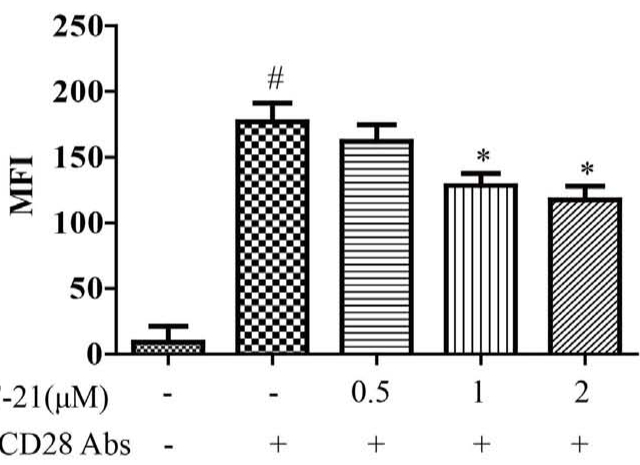

F IFN- $\gamma$ Production by $\mathrm{CDB}^{+}$T Cells

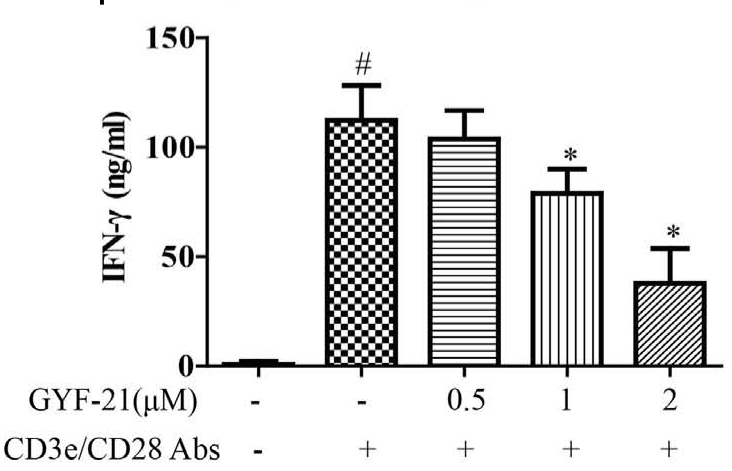

FIGURE 10 | Effects of GYF-21 on the activation, proliferation, and IFN- $\gamma$ secretion of CD8 ${ }^{+} \mathbf{T}$ cells. Splenocytes were treated with or without GYF-21 for $0.5 \mathrm{~h}$. Then the cells were seeded in 24-well plate $\left(1 \times 10^{6}\right.$ cells/well) coated with anti-CD3e mAb $(4 \mu \mathrm{g} / \mathrm{ml})$ and stimulated with soluble anti-CD28 mAb $(2 \mu \mathrm{g} / \mathrm{ml})$ for $24 \mathrm{~h}$. The expressions of CD69 and CD25 on the surface of CD8 ${ }^{+}$T cells were determined by flow cytometry (A-D). Purified CD8 ${ }^{+} \mathrm{T}$ cells were treated with or without GYF-21 for $0.5 \mathrm{~h}$. Then the cells were seeded in 96-well plate $\left(3 \times 10^{5} \mathrm{cells} / \mathrm{well}\right)$ coated with anti-CD3e $\mathrm{lgG}(4 \mu \mathrm{g} / \mathrm{ml})$ and stimulated with soluble anti-CD28 lgG $(2 \mu \mathrm{g} / \mathrm{ml})$ for $72 \mathrm{~h}$. Subsequently, the proliferation of CD8 ${ }^{+}$T cells was determined with CCK-8 (E). The level of IFN- $\gamma$ in the medium was determined by ELISA (F). Data are representative of three independent experiments. ${ }^{\#} P<0.05$ vs. Vehicle, ${ }^{*} P<0.05$ vs. CD3e/CD28 Abs.

significantly suppressed the activation of STAT1/3 and NF- $\kappa$ B signaling pathways but not MAPK signaling pathways. These data indicated that GYF-21 inhibited innate immunity through blocking STAT1/3 and NF- $\kappa$ B signaling pathways. In view of important roles that STAT1 and STAT3 signaling pathways play in the production of Th1 and Th17 cells, GYF-21 may be able to inhibit the differentiation of $\mathrm{CD} 4^{+} \mathrm{T}$ cells into Th1 and Th17 cells.

$\mathrm{CD} 4^{+} \mathrm{T}$ cells are central roles in regulating adaptive immunity responses. Once activated, these cells expanded and differentiated 
into different Th subsets with distinct cytokine profiles and effector functions. The main Th subsets are Th1, Th2, and Th17 cells. Previous studies have revealed that Th1 and Th17 cells are involved and play key roles in pathogenesis of MS (Ogura et al., 2008; McGeachy et al., 2009; Lazarevic et al., 2011; Goldmann and Prinz, 2013; Martin et al., 2016). Recent years, some studies have also reported that $\mathrm{CD} 8^{+} \mathrm{T}$ cells are strongly implicated in the pathogenesis of MS (Ji et al., 2013).

After we revealed the inhibitory effects of GYF-21 on STAT1/3 signaling pathways, we firstly investigated the effects of GYF-21 on the activation and proliferation of $\mathrm{CD}^{+}{ }^{+} \mathrm{T}$ cells. The results showed that GYF-21 didn't suppress upregulation of CD69 and $\mathrm{CD} 25$ on $\mathrm{CD}^{+} \mathrm{T}$ cells and following proliferation of $\mathrm{CD} 4{ }^{+}$ $\mathrm{T}$ cells. Then we further investigated the effects of GYF-21 on the differentiation of naive $\mathrm{CD}^{+}{ }^{+} \mathrm{T}$ cells. The results showed that GYF-21 intensively inhibited the differentiation of naive $\mathrm{CD}^{+} \mathrm{T}$ cells into Th1 and Th17 cells. In addition, further study revealed that GYF-21 could also slightly suppress activation and proliferation of $\mathrm{CD}^{+} \mathrm{T}$ cells, and moderately inhibited IFN- $\gamma$ secretion of $\mathrm{CD}^{+} \mathrm{T}$ cells. These data suggest that GYF-21 may be potential to treat MS by inhibiting adaptive immune function.

In particular, many studies have demonstrated that Th17 cells play most important roles in pathogenesis of MS. The initial development of Th17 cells from naive $\mathrm{CD}^{+} \mathrm{T}$ cells is directed by TGF- $\beta$ in combination with IL- 6 , and this process is enhanced by IL- $1 \beta$ and TNF- $\alpha$, whereas IL-23 is required for the terminal differentiation of Th17 cells into mature effector cells (Ogura et al., 2008; McGeachy et al., 2009; El-Behi et al., 2011; Martin et al., 2016). The present study demonstrated that GYF-21 not only directly inhibited differentiation of naive $\mathrm{CD}^{+} \mathrm{T}$ cells into Th17 cells by blocking IL-6-STAT3 and IL-23-STAT3 signaling pathways but also intensively reduced production of TNF- $\alpha$, IL- 6 , and IL- $1 \beta$ by microglia. These data suggests that GYF-21 is highly valuable to be used for treating MS through significantly inhibiting production of Th17 cells. In our previous study, we had reported a chloride substituted 2-(2-phenethyl)-chromone (GYF-17) with immunosuppressive activity which had similar structure with GYF-21 and marked inhibitory activity on STAT1/3 (main mechanism) and ERK1/2 signaling pathways (Zhu et al., 2016). So we propose that GYF-21 exerts inhibitory effects on STAT1/3 signaling pathways directly but not resulted from downstream response of inhibitory effects on NF- $\kappa$ B signaling pathway. Furthermore, it's well-known that activation of NF- $\kappa \mathrm{B}$ signaling pathway induces stronger

\section{REFERENCES}

Comabella, M., Montalban, X., Munz, C., and Lunemann, J. D. (2010). Targeting dendritic cells to treat multiple sclerosis. Nat. Rev. Neurol. 6, 499-507. doi: 10.1038/nrneurol.2010.112

Dendrou, C. A., Fugger, L., and Friese, M. A. (2015). Immunopathology of multiple sclerosis. Nat. Rev. Immunol. 15, 545-558. doi: 10.1038/nri3871

El-Behi, M., Ciric, B., Dai, H., Yan, Y. P., Cullimore, M., and Safavi, F. (2011). The encephalitogenicity of Th17 cells is dependent on IL-1- and IL-23-induced production of the cytokine GM-CSF. Nat. Immunol. 12, 568-575. doi: 10.1038/ ni.2031

Goldmann, T., and Prinz, M. (2013). Role of microglia in CNS autoimmunity. Clin. Dev. Immunol. 2013:208093. doi: 10.1155/2013/208093 immunological response than ERK1/2 signaling pathway. As well, NF- $\kappa \mathrm{B}$ signaling pathway exerts apoptosis promoting effects, and ERK1/2 signaling pathway play key role in promoting cell proliferation. So double inhibitory effects of GYF-21 on STAT1/3 and NF- $\mathrm{B}$ signaling pathways make it to exhibit stronger immunosuppressive effects and lower cytotoxicity than GYF-17.

\section{CONCLUSION}

In summary, we have discovered that GYF-21, an epoxide 2-(2-phenethyl)- chromone derivative isolated from Chinese agarwood, can significantly suppress innate and adaptive immunity via inhibiting STAT $1 / 3$ and NF- $\kappa$ B signaling pathways and exhibits great potential to be developed into therapeutic agent for MS. Meanwhile, the therapeutic applications of GYF-21 in vivo and the internal association of inhibitory effects of GYF-21 on STAT1/3 and that on NF- $\kappa$ B signaling pathways need further study.

\section{AUTHOR CONTRIBUTIONS}

$\mathrm{Z}-\mathrm{XZ}$ initiated the project and wrote the paper. Z-XZ, RG, Y-FZ, Y-FG, H-XH, and S-SL performed the experiments and analyzed the data. P-FT and Y-LS participated in study design and coordination as well as drafted and revised the manuscript. All authors read and approved the final manuscript.

\section{FUNDING}

This work was supported by funding from National Natural Science Foundation of China, China (No. 81603361 and 81503227), from Beijing University of Chinese Medicine Foundation, China (No. 2015-JYB-JSMS040 and 2015-JYBJSMS039), and the Program for New Century Excellent Talents in University, China (No. NCET-13-0693).

\section{ACKNOWLEDGMENT}

The authors would like to thank Tie-Shan Wang for superior technical assistance.

Goverman, J. (2009). Autoimmune T cell responses in the central nervous system. Nat. Rev. Immunol. 9, 393-407. doi: 10.1038/nri2550

Huo, H. X., Zhu, Z. X., Pang, D. R., Li, Y. T., Huang, Z., Shi, S. P., et al. (2015). Anti-neuroinflammatory sesquiterpenes from Chinese eaglewood. Fitoterapia 106, 115-121. doi: 10.1016/j.fitote.2015.08.009

Hydleburg, M., and D’Aversa, T. G. (2014). Current therapies for multiple sclerosis: a brief review. Austin J. Mult. Scler. Neuroimmunol. 1:4.

Jaillon, S., Galdiero, M. R., Prete, D. D., Cassatella, M. A., Garlanda, C., and Mantovani, A. (2013). Neutrophils in innate and adaptive immunity. Semin. Immunopathol. 35, 377-394. doi: 10.1007/s00281-013-0374-8

Ji, Q. Y., Castelli, L., and Goverman, J. M. (2013). MHC class I-restricted myelin epitopes are cross-presented by Tip-DCs that promote determinant spreading to CD8+ T cells. Nat. Immunol. 14, 254-262. doi: 10.1038/ni.2513 
Lazarevic, V., Chen, X., Shim, J. H., Hwang, E. S., Jang, E., Bolm, A. N., et al. (2011). T-bet represses Th17 differentiation by preventing Runx1-mediated activation of the gene encoding ROR $\gamma$ t. Nat. Immunol. 12, 96-104. doi: 10.1038/ni.1969

Li, Q. T., and Verma, I. M. (2002). NF- $\mathrm{B}$ regulation in the immune system. Nat. Rev. Immunol. 2, 725-734. doi: 10.1038/nri910

Li, W., Cai, C. H., Guo, Z. K., Wang, H., Zuo, W. J., Dong, W. H., et al. (2015). Five new eudesmane-type sesquiterpenoids from Chinese agarwood induced by artificial holing. Fitoterapia 100, 44-49. doi: 10.1016/j.fitote.2014.11.010

Loo, G. V., Lorenzi, R. D., Schmidt, H., Huth, M., Mildner, A., SchmidtSupprian, M., et al. (2006). Inhibition of transcription factor NF- $\kappa \mathrm{B}$ in the central nervous system ameliorates autoimmune encephalomyelitis in mice. Nat. Immunol. 7, 954-961. doi: 10.1038/ni1372

Martin, B. N., Wang, C. H., Zhang, C. J., Kang, Z. Z., Gulen, M. F., Zepp, J. A., et al. (2016). T cell-intrinsic ASC critically promotes Th17-mediated experimental autoimmune encephalomyelitis. Nat. Immunol. 17, 583-592. doi: 10.1038/ni. 3389

McGeachy, M. J., Chen, Y., Tato, C. M., Laurence, A., Joyce-Shaikh, B., Blumenschein, W. M., et al. (2009). The interleukin 23 receptor is essential for the terminal differentiation of interleukin 17-producing effector $\mathrm{T}$ helper cells in vivo. Nat. Immunol. 10, 314-323. doi: 10.1038/ni.1698

Miklossy, G., Hilliard, T. S., and Turkson, J. (2013). Therapeutic modulators of STAT signaling for human diseases. Nat. Rev. Drug. Discov. 12, 611-629. doi: $10.1038 / \mathrm{nrd} 4088$

Nuyts, A. H., Lee, W. P., Bashir-Dar, R., Berneman, Z. N., and Cools, N. (2013). Dendritic cells in multiple sclerosis: key players in the immunopathogenesis, key players for new cellular immunotherapies? Mult. Scler. 19, 995-1002. doi: $10.1177 / 1352458512473189$

Ogura, H., Murakami, M., Okuyama, Y., Tsuruoka, M., Kitabayashi, C., Kanamoto, M., et al. (2008). Interleukin-17 promotes autoimmunity by triggering a positive-feedback loop via interleukin-6 induction. Immunity 29, 628-636. doi: 10.1016/j.immuni.2008.07.018

O'Shea, J. J., Pesu, M., Borie, D. C., and Changelian, P. S. (2004). A new modality for immunosuppression: targeting the JAK/STAT pathway. Nat. Rev. Drug. Discov. 3, 555-564. doi: 10.1038/nrd1441

Rush, C. A., Maclean, H. J., and Freedman, M. S. (2015). Aggressive multiple sclerosis: proposed definition and treatment algorithm. Nat. Rev. Neurol. 11, 379-389. doi: 10.1038/nrneurol.2015.85

Schulz, I., Engel, C., Niestroj, A. J., Zeitschel, U., Menge, K., Kehlen, A., et al. (2011) Heteroarylketones inhibit astroglial interleukin-6 expression via a STAT3/NF$\kappa B$ signaling pathway. J. Neuroinflamm. 8:86. doi: 10.1186/1742-2094-8-86

Schwartz, D. M., Bonelli, M., Gadina, M., and O'Shea, J. J. (2015). Type I/II cytokines, JAKs, and new strategies for treating autoimmune diseases. Nat. Rev. Rheumatol. 12, 25-36. doi: 10.1038/nrrheum2015.167

Shuai, K., and Liu, B. (2003). Regulation of JAK-STAT signalling in the immune system. Nat. Rev. Immunol. 3, 900-911.
Starossom, S. C., Mascanfroni, I. D., Imitola, J., Cao, L., Raddassi, K., Hernandez, S. F., et al. (2012). Galectin-1 deactivates classically activated microglia and protects from inflammation- induced neurodegeneration. Immunity 37, 249-263. doi: 10.1016/j.immuni.2012.05.023

Steinbach, K., Piedavent, M., Bauer, S., Neumann, J. T., and Friese, M. A. (2013). Neutrophils amplify autoimmune central nervous system infiltrates by maturing local APCs. J. Immunol. 191, 4531-4539. doi: 10.4049/jimmunol. 1202613

Strachan-Whaley, M., Rivest, S., and Yong, V. W. (2014). Interactions between microglia and $\mathrm{T}$ cells in multiple sclerosis pathobiology. J. Interferon Cytokine Res. 34, 615-622. doi: 10.1089/jir.2014.0019

Tak, P. P., and Firestein, G. S. (2001). NF-кB: a key role in inflammatory diseases. J. Clin. Invest. 107, 7-11. doi: 10.1172/JCI11830

Torkildsen, Ø., Myhr, K. M., and Bø, L. (2016). Disease-modifying treatments for multiple sclerosis - a review of approved medications. Eur. J. Neurol. 23(Suppl. 1), 18-27. doi: 10.1111/ene.12883

Varga, G., Balkow, S., Wild, M. K., Stadtbaeumer, A., Krummen, M., Rothoeft, T., et al. (2007). Active MAC-1 (CD11b/CD18) on DCs inhibits full T-cell activation. Blood 109, 661-669. doi: 10.1182/blood-2005-12023044

Wu, B., Lee, J. G., Lim, C. J., Jia, S. D., Kwon, S. W., and Hwang, G. S. (2012). Sesquiterpenoids and 2-(2-Phenylethyl)-4H-chromen-4-one (=2-(2Phenylethyl)-4H-1-benzopyran-4-one) derivatives from Aquilaria malaccensis agarwood. Helvetica 85, 636-642. doi: 10.1002/hlca.201100409

$\mathrm{Wu}, \mathrm{G}$. F., and Laufer, T. M. (2007). The role of dendritic cells in multiple sclerosis. Curr. Neurol. Neurosci. Rep. 7, 245-252. doi: 10.1007/s11910-007-0037-z

Zhang, Y. L., and Dong, C. (2005). MAP kinases in immune responses. Cell. Mol. Immunol. 2, 20-27.

Zhu, Z. X., Gu, Y. F., Zhao, Y. F., Song, Y. L., Li, J., and Tu, P. F. (2016) GYF-17, a chloride substituted 2-(2-phenethyl)-chromone, suppressed LPSinduced inflammatory mediator production in RAW264.7 cells by inhibiting STAT1/3 and ERK1/2 signaling pathways. Int. Immunopharmacol. 35, 185-192. doi: 10.1016/j.intimp.2016.03.044

Conflict of Interest Statement: The authors declare that the research was conducted in the absence of any commercial or financial relationships that could be construed as a potential conflict of interest.

Copyright (c) 2017 Guo, Zhao, Li, Gu, Huo, Li, Song, Zhu and Tu. This is an openaccess article distributed under the terms of the Creative Commons Attribution License (CC BY). The use, distribution or reproduction in other forums is permitted, provided the original author(s) or licensor are credited and that the original publication in this journal is cited, in accordance with accepted academic practice. No use, distribution or reproduction is permitted which does not comply with these terms. 